\title{
政uke $\mathfrak{X}$ aw $\mathfrak{J}$ outrual
}

\section{THE CURRENT AND POTENTIAL EQUAL EMPLOYMENT ROLE OF THE NLRB}

\author{
EARL M. LEIKEN*
}

Recent decisions have raised the possibility that the National Labor Relations Act may become a full-fledged equal employment statute. It has long been recognized that a right exists to bring suit against unions to enforce their duty of fair representation. The obligation was initially read into the Railway Labor Act in Steele v. Louisville \& Nashville Railway ${ }^{1}$ and has been extended to the National Labor Relations Act under the Steele rationale. ${ }^{2}$ Originally, the right was enforceable only in the courts, but in the 1960's the National Labor Relations Board began treating violations of the duty of fair representation as unfair labor practices, remediable under the Board's own special procedures. ${ }^{3}$ Although judicial affirmance of these decisions brought the Board power to deal with equal employment violations by unions, it has had no power to similarly deal with employers. This gap may have been filled by a novel theory recently adopted by the Court of Appeals for the District of Columbia Circuit in United Packinghouse Workers v. NLRB. ${ }^{4}$ The court held that the existence of discriminatory working conditions constitutes

* Associate Professor of Law, Case Western Reserve University. A.B. 1964, L.L.B. 1967, Harvard University. The assistance of George Goodridge and Donald McFadden, students at Case Western Reserve Law School, is gratefully acknowledged.

THE FOLLOWING HEREINAFTER CITATIONS WILL BE USED IN THIS ARTICLE:

M. Sovern, Legal Restraints on Racial Discrimination in Employagnt (1970) [hereinafter cited as SOVERN];

United States Comission on Civil Rights Report, Federal Civil Rights ENFORCEMENT EFFORT, 1970 [hereinafter cited as FEDERAL CIVIL Rights EFFORT];

Developments in the Law-Employment Discrimination and Title VII of the Civil Rights Act of 1964, 84 HARv. L. REv. 1109 (1971) [hereinafter cited as Developments-Title VII].

I. 323 U.S. 192 (1944).

2. Syres v. Oil Workers, 350 U.S. 892 (1955); Ford Motor Co. v. Huffman, 345 U.S. 330 (1953).

3. Local 12, URW [Goodyear Tire \& Rubber Co.], I50 N.L.R.B. 312 (1964), affd 368 F.2d 12 (5th Cir. I966); Local I367, ILA [Galveston Maritime Ass'n], 148 N.L.R.B. 897 (1964), affd 368 F.2d 1010 (5th Cir. 1966); Metal Workers Local 1 [Hughes Tool Co.], 147 N.L.R.B. 1573 (1964); Miranda Fuel Co., I40 N.L.R.B. I8I (I962), enforcement denied, 326 F.2d 172 (2d Cir. 1963).

4. 416 F.2d 1126 (D.C. Cir.), cert. denied, 396 U.S. 903 (1969). 
an employer unfair labor practice under section 8(a)(1) of the NLRA because it is an unlawful interference with the section 7 rights of minority employees to engage in concerted activities to improve their working conditions. Under this theory, the discrimination is said to cause a cleavage between the interests of minority workers and others, reducing the likelihood of their working in concert. It also creates apathy or docility in its victims, inhibiting them from asserting their section 7 rights. Though the Board has not yet adopted this view, the General Counsel recently announced a position which is close to the Packinghouse theory. ${ }^{5}$

Taken together, the Steele and Packinghouse decisions raise the interesting possibility that almost every instance of racial, religious, sex or ethnic discrimination in a company within the Board's jurisdiction would be remediable through NLRB procedures. A minority worker discriminated against by a labor union could file an unfair labor practice charge on the theory that the union had violated its duty of fair representation; the victim of employer discrimination could file a charge, arguing that such discrimination inhibits workers in the exercise of their section 7 rights. This result might, in many respects, be a boon to civil rights efforts to improve job opportunities for minorities. The present major federal instrument for equal employment enforcement-Title VII of the 1964 Civil Rights Act ${ }^{6}$-has been severely criticized because of its lack of public enforcement provisions. ${ }^{7}$ The agency which administers Title VII-the Equal Employment Opportunity Commission-has been evaluated by the United States Civil Rights Commission as a "poor, enfeebled thing ... [which] is not much closer to the goal of the elimination of employment discrimination than it was at its inception." 8 Repeated efforts to amend Title VII to provide public enforcement have thus far not been successful. ${ }^{9}$ In contrast, the NLRA provides an existing means of public enforcement. An individual who claims to be the victim of discrimination need only

5. In his quarterly report on significant pending cases, the General Counsel stated that when an employer maintains sex discrimination practices in the face of union opposition, he violates sections 8(a)(1) and 8(a)(3) by demonstrating the union's ineffectiveness and discouraging employees from asserting their section 7 rights to bargain through their union, presumably for the removal of these conditions. 77 BNA LAB. REL. REP. 36 (1971).

6. 42 U.S.C. $\$ \S 2000$ to 2000 e-15 (1964). Title VII is discussed more fully at note 61 infra and accompanying text.

7. R. Nathan, Jobs and Civil Righits 66 (1969); Federal Civil Rights Effort 418. See notes 73-87 infra and accompanying text.

8. FedERAL Civil Rights EFFORT 418.

9. See, e.g., H.R. 10065, 89th Cong., Ist Sess. (1965); S. 3465, 90th Cong., 2d Sess. (1968). An amendment is now before the House Rules Committee. H.R. 1746, 92d Cong., 1st Sess. (1971). See also note 96 infra. 
file a complaint with the NLRB's General Counsel. If probable cause for such discrimination were found, the General Counsel's office would then assume the entire burden of prosecuting the charge before either the Board or the courts. ${ }^{10}$

The Board's wholesale involvement in equal employment matters would, however, raise troubling questions. The most important concerns the language and structure of the NLRA. There is no evidence that Congress expressly intended it to serve as an instrument for the protection of equal job opportunities for minority groups. In fact, the statute was primarily designed for a different purpose-to encourage unionization and promote collective bargaining. ${ }^{11}$ Moreover, there is at least some question about the Board's proceeding in this area in disregard of the highly specific and carefully limited procedures Congress has established under Title Vll for employment discrimination problems. Inasmuch as the NLRB already has a heavy case load in areas to which the statute seems expressly directed, ${ }^{12}$ one questions the wisdom of an assumption of an additional burden without strong reason. Finally, there is some question whether the NLRB could proceed in this area without interfering with the work of other equal employment agencies. Employers and unions are already subject to heavy equal employment regulation, ${ }^{13}$ and at times the proliferation of agencies with dissimilar approaches in this field has served to becloud effective law enforcement. ${ }^{14}$ In light of all

10. See National Labor Relations Act, § 3(d), 29 U.S.C. § 153(d) (1964).

11. Id. \& ISI. Section 1 of the Act sets forth its purpose by stating:

It is hereby declared to be the policy of the United States to eliminate the causes of certain substantial obstructions to the free flow of commerce. . . by encouraging the practioe and procedure of collective bargaining and by protecting the exercise by workers of full freedom of association, self-organization and designation of representatives of their own choosing. ...

12. In 1970, the NLRB caseload included over 12,000 representation cases and 21,000 cases involving unfair labor practices. This was an increase of 5,500 cases over the number five years previously. See 77 BNA LAB. ReL. ReP. $42-43$ (1971), (Statement by former NLR B Chairman Frank W. McCullough in appearance before Congressional Committee studying NLRB's activities). McCullough referred to the NLRB's burden as an "increasing and crushing volume of Board work. . . [ [with] resulting delays and frustrations."

13. In addition to Title VII, employers who work on government contracts or federallyassisted construction programs are subject to equal employment requirements under Exec. Order No. 11,246, 3 C.F.R. at 424 (1971), 42 U.S.C. $\$ 2000$ (Supp. V, 1970). Many cmployers are regulated by state fair employment practice commissions. See SOVERN 19-60. Unions are regulated in their apprenticeship programs by equal employment regulations of the Labor Department's Bureau of Apprenticeship and Training. 29 C.F.R. \$\$ 30.1 -.16 (1971).

14. In Crown Zellerbach Corp. v. United States, 416 F.2d 980 (5th Cir. 1969), for example, a series of problems arose because of inconsistent positions taken on the same case by various equal employment agencies. Id. at 984-85. These problems are discussed in Farmer, Equal Employment Opportunity-Case Study of a Chaotic Administration, 44 FLA. B.J. 400 (1970). 
these factors, some commentators have strongly suggested that the NLRB stand aside in areas otherwise covered by Title VII. ${ }^{16}$ The Packinghouse decision, however, adopts exactly the opposite position, calling for an extension of the Board's responsibility in equal employment enforcement, and illustrates the need for a re-examination of the Board's entire role in this area.

The Steele decision ${ }^{16}$ is the great grand-daddy of all subsequent developments in the equal employment opportunity area. The Railway Labor Act ${ }^{17}$ made the Brotherhood of Locomotive Firemen and Enginemen the exclusive bargaining representative of all firemen employed by the railroad. The union, however, made an agreement with the railroad that would eventually have led to the advancement of whites and the exclusion of all blacks from the service. Despite the lack of explicit language in the Railway Labor Act requiring fair representation, the Supreme Court held that the union's conduct was unlawful, arguing that the term "representative" in the fourth paragraph of section 2 implied an obligation to act on behalf of all the employees that the union was supposed to represent. ${ }^{18}$ It also stated that the Act deprived minorities of a right they would otherwise have had - to bargain individually with the employer. ${ }^{19}$ The Court held that in granting such extensive power to unions, Congress had impliedly imposed upon the unions a legislative-type obligation to equally protect those they represented. ${ }^{20}$ In the absence of any available administrative remedy the Court found that the judiciary had power to enjoin and grant damages for union discrimination. ${ }^{21}$

In subsequent cases, the Steele doctrine has been extended to prohibit unfair union treatment of minorities who were not members of the bargaining unit ${ }^{22}$ and to require that unions act affirmatively to oppose employer discrimination. ${ }^{23}$ Inasmuch as the policies behind Steele are equally applicable to unions operating under the National Labor Relations Act, the Court eventually applied Steele to judicial enforcement of fair representation under the latter statute. ${ }^{24}$ It must

15. Sherman, Union's Duty of Fair Representation and the Civil Rights Act of 1964, 49 MiNN. L. REv. 771 (1965). It has also been argued that the NLRB should defer to the EEOC if the latter agency acquires enforcement powers by amendment of Title VII. See Note, Allocating Jurisdiction Over Racial Issues Between the EEOC and NLRB: A Proposal, 54 CORNELl L. REV. 943 (1969).

16. 323 U.S. 192 (1944).

17. 45 U.S.C. $\$ \S 151-88$ (1964).

18. 323 U.S. at 199.

19. Id. at 200 .

20. Id. at 202.

21. Id. at 207.

22. Brotherhood of R.R. Trainmen v. Howard, 343 U.S. 768 (1952).

23. Conley v. Gibson, 355 U.S. 41 (1957).

24. See cases cited at note 2 supra. 
be noted, however, that there is a major difference between the two acts in the unique role played by the NLRB under the NLRA. Most rights and liabilities under that statute are enforced through the Board rather than directly in court.

While at the time of Steele the Board had no authority to remedy union discrimination, since the Act contained only employer unfair labor practices, the addition of union unfair labor practices in the Taft-Hartley amendments ${ }^{25}$ gave the Board potential power in this area. Perhaps because Congress had not explicitly created a right of fair representation in Taft-Hartley, that authority was not utilized until $1962^{26}$ when the Board held in Miranda Fuel Co. ${ }^{27}$ that a union which caused an employer to arbitrarily reduce the seniority of a worker had committed an unfair labor practice by violating its duty of fair representation. Though this decision was reversed by the Court of Appeals for the Second Circuit, ${ }^{28}$ the Board continued to adhere to its Miranda view in cases which followed. In Independent Metal Workers, Local 1 [Hughes Tool Co. $]{ }^{29}$ for example, the doctrine was applied to union racial discrimination, and the Board's judgment on this question was affirmed in a subsequent case by the Fifth Circuit Court of Appeals. ${ }^{30}$ Since the doctrine has application to any union

25. Labor Management Relations Act (Taft-Hartley Act) $\S 8(b), 29$ U.S.C. $\S 158(b)$ (1964).

26. The evolution in the Board's and General Counsel's thinking on this issue is well summarized in Herring, The "Fair Representation" Doctrine: An Effective Weapon Against Union Racial Discrimination?, $24 \mathrm{MD}$. L. Rev. 113, 148-58 (1964). In the early 1950's, the General counsel took the position that the denial of fair representation was not an unfair labor practice. This view was specilically stated in an amicus curiae brief hiled in Ford Motor Co. v. Huffman, 345 U.S. 330 (1953), and in 1954 the General Counsel affirmed a regional director's refusal to issue an $8(\mathrm{~b})(\mathrm{l})$ complaint in a case where a union failed to protest a company rule which discriminated against Negroes. Case No. 1047, 35 L.R.R.M. 1130 (1954). However, in 1956 there was an indication of a shift in the General Counsel's position-he refused to issue a complaint against a union in a case involving racial discrimination solely because he found no evidence that the union had instigated the discrimination. Case No. K311,37 L.R.R.M. 1457 (1956). In 1958, the Board accepted without comment a decision by one of its trial examiners based on his opinion that a union violated $8(b)(1)(A)$ when it defaulted on its duty of fair representation, though the case could have been disposed of on other grounds. Local 229, UTW [J. Radley Metzger Co.], 120 N.L.R.B. 1700 (1958). Finally, in Miranda Fuel Co., 140 N.L.R.B. 181 (1962) the Board held explicitly that a violation of the duty of fair representation is an unfair labor practice.

27. 140 N.L.R.B. 181 (1962).

28. NLRB v. Miranda Fuel Co., 326 F.2d 172 (2d Cir. 1963).

29. 147 N.L.R.B. 1573 (1964).

30. Local I2, URW v. NLRB, 368 F.2d 12 (5th Cir. 1966), cert. denied, 389 U.S. 837 (1967). The D.C. Circuit Court of Appeals has also upheld the Board's Miranda theory in a non-racial case. Truck Drivers Local 568 v. NLRB, 379 F.2d 137 (D.C. Cir. 1967).

Thus far, however, the Supreme Court has chosen not to rule on the theory. It denied certiorari in two cases where it had an opportunity to make such a ruling. Local 12, URW 
action on the basis of "unfair, irrelevant or invidious factors," 31 it has widespread potential for attacking union discrimination against any minority group worker, as well as for attacking union failure to actively oppose employer discrimination..$^{32}$

\section{Discrimination Against Minorities as a Union UNFair Labor Practice}

\section{Constitutional Basis for the Doctrine}

Though there may have been some doubt on the question in 1944, it is now perfectly clear that the Steele decision is based on a policy of constitutional necessity. ${ }^{33}$ The federal and state governments have a constitutional obligation to refrain from arbitrary action against minority group members under the fifth $^{34}$ and fourteenth ${ }^{35}$

v. NLRB supra and Local 1367, ILA [Galveston Maritime Ass'n], 148 N.L.R.B. 897 (1964), aff d 368 F.2d 1010 (5th Cir. 1966). Certiorari was denied in both cases. 389 U.S. 837 (1967). The Court also failed to take an explicit position on this issue in Republic Steel Corp. y. Maddox, 379 U.S. 650, 652 (1965) and Humphrey v. Moore, 375 U.S. 335, 344 (1964).

31. Miranda Fuel Co., 140 N.L.R.B. 181, 185 (1962).

32. See Conley y. Gibson, 355 U.S. 41 (1957). There are several aspects of the Board's involvement in this general area which are not within the scope of this article. First, as indicated in Yiranda, the Board's theory regarding the duty of fair representation as an unfair labor practice extends beyond minority employees to the protection of any employees treated by their union in "an unfair, irrelevant or invidious" manner. Second, the Board in the 1960's did more with regard to discriminating unions than to hold them guilty of unfair labor practices. It also refused to apply its normal contract bar rule to protect a union which discriminated, Pioneer Bus Co., 140 N.L.R.B. 594 (1962), and rescinded its certification of a union which discriminated, Metal Workers Local I [Hughes Tool Co.], I47 N.L.R.B. 1573 (1964). These sanctions constitute a withdrawal by the Board, in the case of discriminating unions, of protections which would otherwise normally be granted. For an analysis of the Board's role in these areas, see SOVERN 156-60.

One might argue that the Board would satisfy any responsibilities it has in this area by simply denying its protections to unions which discriminate. However, many unions, such as the skilled building trade unions, bastions of discrimination, are now so powerful that a loss of Board certification would have no effect on their power. Against other unions, decertification is a hcavy, inflexible weapon. It may be entirely inappropriate in cases where unions committing isolated acts of discrimination would be fatally weakened by decertification. The unfair labor practice provisions allow for more flexible, specific remedies.

33. Note that Justice Murphy's concurring opinion suggested this possibility in Steele, 323 U.S. at 208.

34. U.S. Const. amend. V. In Bolling v. Sharpe, 347 U.S. 497 (1954), the Supreme Court held that "discrimination may be so unjustifiable as to be violative of due process." Id. at 499. In that case, and in Hurd v. Hodge, 334 U.S. 24 (1948), the companion casc to Shelley y. Kraemer, 334 U.S. 1 (1948), the Court held that the federal govcrnment was proscribed from either subsidizing (Bolling) or judicially approving (Hurd) racial discrimination. Though the question has not been explicitly resolved by the Supreme Court, it clearly appears that the federal government is restricted from engaging in discrimination against minorities to the same extent as the states. It would be "unthinkable" for the federal government to have a lesser obligation. See W. Lockhart, Y. KAMISAR, J. Choper, CONSTITUTIONAL LAW 1207 (4th ed. 1970). 
amendments, respectively. In the last quarter-century the Supreme Court has taken major strides in extending this obligation, through the state action concept, ${ }^{36}$ to quasi-private associations like labor unions which function with considerable governmental support and delegated public authority. In Burton v. Wilmington Parking Authority ${ }^{37}$ the Court held that a restaurant which leased its facilities from a state parking authority had violated the equal protection rights of blacks by refusing to serve them. The Court said that by leasing its property to the restaurant, the state had "so far insinuated itself into a position of interdependence" with the restaurant "that it [became] a joint participant in the challenged activity which, on that account," was subject to fourteenth amendment restrictions..$^{38}$ The Court noted that the parking authority could have forbidden the lessee's discriminating and that "by its inaction ... [it] elected to place its power, property and prestige behind the admitted discrimination." $" 39$

Without a requirement of fair representation, the federal government would almost assuredly be more implicated in labor union discrimination than the state was in Burton. Through the NLRA, the federal government assists labor unions in their organizational efforts and forces employers to bargain with the unions after they are elected by a majority of the employees; it protects those who are involved in union activity from punitive action by employers; and most importantly, it is the very source of the power which the unions use to discriminate since the Act gives the union exclusive authority to represent minority employees. Without the Act,

The cases referred to in the text are primarily race discrimination cases. However, it is clear that equal protection obligations apply to the same extent to discrimination against ethnic or religious minorities. See Korematsu v. United States, 323 U.S. 214 (1944). It is also clear that the equal protection clause protects women from governmentally supported sex discrimination. Although the Supreme Court has in the past used a very permissive standard of zeview for sex classifications, see Comment, Sex Discrimination and Equal Protection: Do We Need A Constitutional Amendment?, 84 HARv. L. REv. 1499 (1971), it recently found such a classification to be in violation of the equal protection clause, Reed v. Reed, 40 U.S.L.W. 4013 (U.S. Nov, 23, 1971). Thus, the government has a constitutional responsibility to see that labor unions do not discriminate against women.

35. U.S. ConsT. amend. XIV, \& I.

36. See generally Van Alystyne, Mr. Justice Black, Constitutional Review, and the Talisman of State Action, 1965 DUKE L.J. 219.

37. 365 U.S. 715 (1961).

38. Id. at 725 .

39. Id. 
these employees would be free to make their own bargain, ${ }^{40}$ and by not requiring fair representation, the federal government "would be placing its power, property and prestige behind the discrimination." In Public Utilities Commission v. Pollak," first and fifth amendment standards were held applicable to a privately owned public utility transit company largely on the basis that it was regulated and licensed by the federal government. Labor unions are heavily regulated not only by the NLRA but also by other comprehensive federal legislation. ${ }^{42}$ They hold, therefore, something very much like a federal "license" to operate in representation of employees through the form of Board certification of their status as bargaining agents. ${ }^{43}$

A second line of authority provides support for the conclusion that labor unions have a constitutional obligation to provide fair treatment to minority workers. Under these cases, private associations which take on governmental-type responsibilities by delegation from the state are subject to constitutional regulation in their use of those powers. ${ }^{44}$ It could be argued that most of these cases apply constitutional standards to activities that are more "typically" governmental than a labor union's representation of workers in

\footnotetext{
40. Steele v. Louisville \& Nashville Ry., 323 U.S. 192, 200 (1944).

41. 343 U.S. 451 (1952).

42. E.g., Labor Management Reporting and Disciosure Act (Landrum-Griffin Act) $\S \S 101-231,29$ U.S.C. $\S \S 401-531$ (1964).

43. The Court has already held constitutional standards applicable to a labor union in IAM v. Street, 367 U.S. 740 (1961). In that case, a union was held to have violated the first and fifth amendment rights of a political dissenter by using his dues, obtained under a union shop agreement, for political purposes with which he disagreed. The requisite state action was found from a section of the Railway Labor Act which permitted the union shop and nullified any state right to work law to the contrary. A broader rationale has, however, been suggested for the Street decision:
}

The case for governmental action might have been made more persuasively if more broadiy [in Street]. Consider that the union shop provision of the Railway Labor Act is but one section of a comprehensive regulatory statute, a stalute establishing a federal program for the railroads designed to encourage collective bargaining. Thus, the statute's union shop provision ... embodies a federal policy which encourages the formation of union security provisions. The statute says to the unions, go ahead and do what your philosophy tells you to do. This encouragement might be thought to provide sufficient government involvement to make the first and fifth amendments applicable. Indeed, perhaps the extent to which federal statutes have given unions control over the economic well-being of the bulk of employees in an enterprise may be considered a delegation to the union of governmental power ..... H. Wellington, LABOR AND tHe LegAL PROCESS 244 (1968).

44. "[W] hen private individuals or groups are endowed by the state with powers or functions governmental in nature, they become agencies or instrumentalities of the State and subject to its constitutional limitations." Evans v. Newton, 382 U.S. 296, 299 (1966). 
collective bargaining with the employer ${ }^{45}$-the operation of a company town, ${ }^{46}$ the selection by political parties of candidates for election as public officials, ${ }^{47}$ and the operation of a long-time municipal park by a private organization. ${ }^{48}$ However, it may be sufficient that the activities performed by the private group closely resemble governmental functions. Thus, in Local 590 v. Logan Valley Plaza, Inc., ${ }^{49}$ first amendment standards were held applicable to a private shopping center, largely because it resembled the company town situation in Marsh v. Alabama. ${ }^{50}$ Under this view, the Marsh line may well have applicability to labor unions. Their collective bargaining activities have been described by the Supreme Court as a system of "industrial self-government," 51 and the agreements they adopt have been treated like legislative enactments or the creation of a "new common law." 52 The power to engage in these activities is largely delegated to labor unions by the government through their "exclusive representative" powers under the NLRA..$^{53}$ Thus, labor unions using their delegated power to engage in quasi-governmental functions are also subject to governmental responsibilities not to discriminate against the minority groups they represent.

Finally, Shelley v. Kraemer ${ }^{54}$ and its companion case, Hurd $v$. Hodge, ${ }^{55}$ proscribe the judiciary from enforcing private discriminatory agreements. As a result of the passage of section 301 of the Taft-Hartley Act ${ }^{56}$ making labor agreements enforceable in the federal courts, both federal and state courts are now heavily involved

45. See Symposium-Individual Rights in Industrial Self-Government, 63 Nw. U.L. REV. 4,25 (1968), which provides a comprehensive discussion of the applicability of this line of cases to the general industrial relations system.

46. Marsh v. Alabama, 326 U.S. 501 (1946).

47. Terry v. Adams, 345 U.S. 461 (1953); Smith v. Allwright, 321 U.S. 649 (1944).

48. Evans v. Newton, 382 U.S. 296 (1966).

49. 391 U.S. 308 (1968).

50. 326 U.S. 501 (1946).

51. United Steelworkers v. Warrior and Gulf Nav. Co., 363 U.S. 574, 580 (1960). The Court has described the collective agreement as "a generalized code to govern a myriad of cases which draftsmen cannot wholly anticipate ... [calling] into being a new common law-the common law of a particular industry or of a particular plant." Id. at 578-79.

52. Id. at 580 .

53. One could even argue that the federal government has delegated to the collective bargaining process some of its authority to legisiate on wages, hours, and employment conditions for the national welfare. Symposium, supra note 44, at 25, 26.

54. 334 U.S. 1 (1948).

55. 334 U.S. 24 (1948).

56. Labor-Management Relations Act (Taft-Hartley) § 301, 29 U.S.C. § 185 (1964). 
in enforcing collective bargaining contracts. ${ }^{57}$ The policies of Shelley and Hurd strongly support the creation of a duty of fair representation as a means of helping assure that courts do not enforce agreements that are discriminatorily negotiated or administered. The duty of fair representation performs this function by acting as a check on union behavior at each stage of the negotiation and administration process to see that minority rights are not violated.

It is important to understand the limits of this argument. The position set forth above is not based on the theory that all labor union activities are subject to constitutional regulation. In matters of internal union affairs, there are strong public policies which favor free private association and which may argue against subjecting union decisions to judicial review under constitutional standards. ${ }^{58}$ However, when labor unions use their express statutory power to affect the employment status of minorities, the government and the courts have a clear constitutional obligation to assure that such workers receive fair treatment. ${ }^{59}$

\section{Union Discrimination-The NLRB and Other Sources of Relief}

The NLRB and the Judiciary. One can argue that even if the duty of fair representation of minority employees is constitutionally necessary, the government satisfies its responsibilities by the existence of a judicial remedy for unfair representation, which was recognized

57. Such agreements were enforceable to some extent in state courts even before the passage of this section. However, many state courts would not assert jurisdiction over unions on the theory that they are not "suable entities." This section was designed to create a federal forum for the enforcement of such agreements. S. REP. No. 105, 80th Cong., ist Sess. 15-18 (1947). In Textile Workers v. Lincoln Mills, 353 U.S. 448 (1957) the seetion was interpreted as a grant of authority to the judiciary to fashion a new substantive law of collective bargaining agreement enforcement, which is also applicable to the state courts under the Supremacy Clause. See also Boys Market, Inc. v. Retail Clerks, Local 770, 398 U.S. 235 (1970).

58. See H. Wellington, supra note 43 , at 245 (1968). See also Oliphant v. Firemen \& Enginemen, 156 F. Supp. 89 (N.D. Ohio), cert. denied, 355 U.S. 893 (I957), affd 262 F.2d 359 (6th Cir. 1958), cert. denied, 359 U.S. 935 (1959). Contra Betts v. Easley, 161 Kan. 459, 169 P.2d 831 (1946). See generally Gould, Some Limitations Upon Union Discipline Under the National Labor Relations Act: The Radiations of Allis-Chalmers, 1970 DUKE L.J. 1067.

59. The government's constitutional responsibility extends beyond unions presently certified by the Board. It clearly extends to those once certified who no longer hold a Board certification since the government was heavily involved in their initial achievement of power. Moreover, it should probably extend to unions which have achieved management recognition since 1935, even though they have never had formal Board certification. The labor movement is closely interrelated. It is clear that the existence of the Act and the Board's activities on behalf of some unions have "encouraged and supported" the achievements of all other successful unions and that all union activity should come within the meaning of Burton v. Wilmington Parking Authority, 365 U.S. 715 (1961). 
in Vaca v. Sipes. ${ }^{60}$ In light of the Vaca decision that the judicary will continue to exercise its historical role in this area despite recent Board decisions, it might be argued that the Board can in good conscience withdraw from the field and allow the courts to enforce the rights of minority workers. Policy considerations, however, clearly indicate a vital need for the Board's continued presence.

The right to fair representation, having been read into the NLRA by the Court, ${ }^{61}$ is as much a part of the statute as any other provision. It would be anomalous to require a victim of sex or race discrimination by a labor union to go to court to enforce his rights while the agency with primary responsibility for the administration of the Act looked the other way. Moreover, a union and employer can obtain free enforcement of their rights through the Board's General Counsel; if the Board were permitted to abandon the field, these rights would have a higher priority than the employees' rights to fair treatment from their unions. This would be especially unfair because the employee will normally be least likely to have the resources necessary for private judicial suit. The paucity of cases in twenty-five years of experience with the judicial doctrine of fair representation ${ }^{62}$ indicates that the expense of going to court has been a major deterrent to private suit, ${ }^{63}$ and that judicial enforcement is an inadequate solution to employee discrimination problems. From an administrative viewpoint, the Board is almost surely more effective in dealing with problems in this area than the judiciary. Those in the General Counsel's office will generally have a broader background and more expertise in prosecuting labor relations cases than less specialized private attorneys. On the hearing side, Board members

60. 386 U.S. 171 (1967). This case resolved the question whether violations of the union's duty of fair representation are within the exclusive jurisdiction of the NLRB. Specifically, the question was whether the broad pre-emption doctrine of San Diego Bldg. Trades Council v. Garmon, 359 U.S. 236 (1959) - which held that activities arguably protected or prohibited by the NLRA are within the Board's exclusive jurisdiction-applied to this situation. The Court held that it did not apply to fair representation cases, largely on the basis of the judiciary's carlier entry into that field.

61. See note 2 supra and accompanying text.

62. See notes 25-28 supra and accompanying text.

63. The ample powers of the judiciary notwithstanding, Negro resistance to union discrimination has rarely included reliance on the unequivocal holdings in Steele and the decisions following it. Any of the busy state FEPC's receive far more employment complaints from Negroes in one year than all of the courts have received in Steele in over 20 years. In part, this may be attributed to the expense of obtaining counsel familar with the intricacies of our federal labor legislation and of pursuing the matter through the courts. In other words, the high cost of suing has probably robbed the right to be fairly represented of much of its efficacy. SOVERN 155. 
and trial examiners are likely to bring a lifetime of labor relations experience to their jobs, and can be expected to be particularly perceptive regarding union discriminatory practices whereas, it would be rare to find a lower court judge with the benefit of comparable experience. Finally, the Board-hearing all cases itself-has the capacity to develop uniform policies in this area. ${ }^{64}$ This argument cannot be claimed for the judicial doctrine which would leave enforceability to all federal and state courts.

The NLRB and Title VII. Title VII of the Civil Rights Act of $1964^{65}$ gives comprehensive substantive rights to victims of labor union discrimination. It makes it unlawful for a union to discriminate in its membership policies, to limit or deprive anyone of an employment opportunity because of his race, color, religion, sex or national origin, or to cause an employer to discriminate against any individual for such reason. ${ }^{66}$ Almost any union discrimination against minority groups that might be prohibited by the NLRA is therefore dealt with explicitly under Title VII. For this reason, some commentators have suggested that the NLRB refrain from using its unfair labor practice powers in such cases and defer to the Civil Rights statute. ${ }^{67}$

It is important to note at the outset that Title VII does not as a matter of law preclude the use of other equal employment remedies. There is nothing in the statute which makes it an exclusive remedy for employment discrimination. The Justice Department has taken the position that Title VII was designed independently of the NLRA and was not intended to limit the role of the NLRB in this area. ${ }^{68}$

64. See Wellington, Union Democracy and Fair Representation, 67 YALE L.J. 1327, 135761 (1958), in which the author discusses the difficulty that courts have had in formulating appropriate standards in this area and suggests, four years in advance of the Miranda Fuel Co. case that the NLRB may be uniquely capable of doing the job.

65. 42 U.S.C. $\$ 2000$ e to 2000 e-15 (1964).

66. Id. §2000e-2(c).

67. See note 15 supra.

68. Nothing in Title VII or anywhere else in this bill affects rights and obligations under the NLRA and the Railway Labor Act. Of course, Title VIl is not intended to and does not deny to any individual, rights and remedies which he may pursue under other Federal and State statutes. If a given action should violate both Title VII and the National Labor Relations Act, the National Labor Relations Board would not be deprived of jurisdiction. To what extent racial discrimination is covered by the NLRA is not entirely clear. I understand that the National Labor Relations Board has presently under consideration a case involving the duties of a labor organization with respect to discrimination because of race. At any rate, Title VII would have no effect on the duties of an employer or labor organization under the NLRA or under the Railway Labor ACl and these duties would continue to be enforced as they are now. . . 110 CoNG. REc. 7206-07 (1964) (letter from the Justice Department to Senator Clark). 
The Senate, moreover, resoundingly defeated an amendment which would have made Title VII the exclusive remedy for employment discrimination. ${ }^{69}$ This position has been substantiated by the courts who have thus far dealt with the question by concluding that Title VII does not preempt the NLRB. ${ }^{70}$

The question, therefore, is one of policy and any answer must take into account Title VII's record of severe weakness in enforcing equal job opportunity. As mentioned previously, the United States Civil Rights Commission takes a very dim view of the effectiveness of the chief administering agency of the Title-the Equal Employment Opportunity Commission. ${ }^{71}$ The EEOC's own studies have demonstrated Title VII's failures in dealing with one of the most significant and prominent areas of labor union discrimination-union blockage of jobs for minorities in the skilled building trades..$^{72}$

The major problem with the Civil Rights Act as now written is that it simply does not provide for adequate public enforcement. The EEOC is designed to perform a persuading, mediating and conciliating role. ${ }^{73}$ Unfortunately, as the number of its cases has grown, the Commission has had a declining record of success in conciliation efforts. In 1969, for example, it failed to achieve even partial success in remedying discrimination by agreement in more than $50 \%$ of its cases. ${ }^{74}$ This lack of success may be attributable to the inability of the Commission to bring meaningful pressure against individuals charged with discrimination, thereby providing them with little incentive to settle voluntarily. ${ }^{75}$ This puts the individual complainant in an anomalous position. If he wishes to go to court

69. The amendment read as follows:

[Title VII] shall constitute the exclusive means whereby any department, agency or instrumentality in the executive branch of the Government or any independent agency of the United States, may grant or seek relief from or pursue any remedy with respect to, any employment agency, labor organization or joint labor-management committee covered by this title, if such employment practice may be the subject of a charge or complaint filed under this title. 110 CoNG. REc. 13650 (1964).

70. United Packinghouse Workers v. NLRB, 416 F.2d 1126, 1133-34 n.11 (D.C. Cir. 1969);

Local 12, URIV v. NLRB, 368 F.2d 12, 24 (5th Cir. 1966).

71. See note 8 supra and accompanying text.

72. See Leiken, Preferential Treatment in the Skilled Building Trades: An Analysis of the Philadelphia Plan, 56 CORNELl L. REV. 84, 86 n.14 (1970).

73. Developments-Title VII 1196-98.

74. FEDERAL CIVIL RIGHTS EFFORT 327. A successful conciliation effort is one which results in an agreement by the charged party, the EEOC and the charging party. In a partially successful agreement, the charged party agrees to discontinue the discrimination but refuses to sign an agreement. FEderal. CiviL Rights EFFORT 327 n.75.

75. Developments-Tille VII 1201. 
to enforce his rights, he can normally do so sixty days after the filing of his charge. ${ }^{76}$ If he takes this approach, however, he is allowing insufficient time for the conciliation process to operate and he loses the benefit of the mediation approach entirely. ${ }^{77}$ If he waits for conciliation, he can expect a delay of almost two years, ${ }^{78}$ at which time he may be in no better position than when he started.

Title VII's main potential comes from its individual court suit provisions, but there are substantial deterrents to the exercise of this power. Victims of discrimination are likely to be fearful of the severe expense of protracted litigation. Though the Act does contain provisions for judicial appointment of attorneys for plaintiffs, this is a matter entirely within the judge's discretion and no funds are provided to pay the attorneys' fees. ${ }^{79}$ The attorney is therefore dependent for payment upon victory and a percentage of his client's recovery. In addition, the Act provides that losing litigants may be required to pay the expenses of their prevailing opponents, ${ }^{80}$ and thus suffer a severe penalty for having brought suit. There is, moreover, no experienced bar to take on litigation in this area. ${ }^{81}$ In light of these factors it is not surprising that the great majority of private claimants have been discouraged from filing actions. EEOC Chairman William H. Brown III has, in fact, indicated the scope of this problem by noting that private suits are now brought in fewer than ten per cent of the cases in which the EEOC is unable to obtain private settlement. ${ }^{82}$

The Attorney General does have power in "pattern and practice" cases to bring suit for violations of Title VII. ${ }^{83}$ This statutory power, however, applies only to limited classes of cases where instances of discrimination are unusually severe in a particular industry or area. It is enforced by the Civil Rights Division of the Justice Department which is already understaffed and whose resources are principally diverted to other areas-such as discrimination in housing and schools. ${ }^{84}$ The power to date has been used sparingly, ${ }^{85}$ and where it

76. Id. at $1207 \mathrm{n} .71$.

77. Id. at $1201-02$.

78. Hearings on S. 2453 Before the Subcomm. on Labor of the Senate Conm. on Labor and Public Welfare, 91st Cong., Ist Sess. (1969).

79. 42 U.S.C. $\S 2000 \mathrm{e}-5(k)(1964)$.

80. Id. $\S 2000 \mathrm{e}-5(\mathrm{k})$.

81. Federal Civiz Rights EfFort 338.

82. Hearings on $S .2453$, supra note 78 , at 40.

83. 42 U.S.C. \& 2000e-6(a) (1964).

84. Federal Civil Rigits EfFort 372.

85. From the effective date of Title VII through early 1971, only 57 pattern or practioc suits had been brought by the Department of Justice. Developments-Title VII 1109, 1230 n.206. 
has been invoked it has been to establish precedent rather than to enforce the statute. ${ }^{86}$ For all of these reasons, the vast majority of Title VII violations continue uncorrected. ${ }^{87}$

By contrast, the NLRA is designed to be implemented by public, rather than private, enforcement through the office of the General Counsel. In this respect, it plays a unique role in the whole federal civil rights scheme. ${ }^{88}$ Though Board conciliation may also require a long time, an individual is at least guaranteed public enforcement at the end of the line if conciliation is unsuccessful. The General Counsel also has power to seek immediate temporary relief under section $10(\mathrm{j}){ }^{89}$ Thus far, the Board appears to have been more successful than the EEOC in disposing of cases through the conciliation process. ${ }^{90}$ Though the Board has no "cease and desist" powers of its own, it does have authority to sue in federal court to enforce its decisions. Because of this power and the considerable deference reviewing courts pay to Board decisions, ${ }^{91}$ there is a very great likelihood that those charged with discrimination will yield to Board pressure in the conciliation process.

Obviously, the Board's assertion of a role in this area raises some problems of overlap with Title VII. There is a definite need for greater coordination of the efforts of the various agencies working on civil rights in employment..$^{92}$ In light of its potential in this area, it is unfortunate that a representative from the Board was not included

86. Id. at 1231-32.

87. Id. at 1252 .

88. The other major federal statute which has been interpreted to provide a remedy for job discrimination, 42 U.S.C. $\S 1981$ (1964), also relies on private suits for enforcement. See Central Contractors Ass'n v. Local 46, IBEW, 312 F. Supp. 1388 (W.D. Wash. 1969). Exec. Order No. 11246, 30 Fed. Reg. 12319 (1965), as amended, Exec. Order 11375, 32 Fed. Reg. 14303 (1967), is designed to eliminate job discrimination on federal contracts and on federally assisted construction projects. However, it is inadequate as a vehicle for combatting union discrimination since it specifically regulates only employer practices and contains no meaningful provisions with regard to unions. See Leiken, supra note 72, at 95. The Labor Department has regulations requiring non-discrimination in registered union apprenticeship programs. 29 C.F.R. $\$ 30.1-.16$ (1970). However, this program is ineffective since the penalty for violation of the regulations-deregistration-takes away no meaningful benefits and is little more than a slap on the wrist. Leiken, supra note 72 , at 97 . The inadequacies of most state civil rights agencies in the job discrimination area are very well described in SOVERN 19-60.

89. National Labor Relations Act § 10(j), 29 U.S.C. § I60(j) (1964).

90. The NLRB in an average year settles through voluntary withdrawal of the charge, settlement agreement, or dismissal, approximately $90 \%$ of the charges it receives. See A. Cox \& D. BOK, LABOR LAw: CASES AND Materials 138 (7th ed. 1969).

91. NLRB v. Walton Mfg. Co., 369 U.S. 404, 405 (1962); Universal Camera Corp. v. NLRB, 340 U.S. 474, 488 (19S1); NLRB v. Hearst Publications, 322 U.S. 111, 130-31 (1944). See also Developments-Title VII 1201.

92. See Federal Civil Rights Effort 422. 
on the Interagency Coordinating Board which has recently been formed. ${ }^{93}$ However, the Board could eliminate most of the risks of duplicative procedures by paying proper deference on its own to Title VII. In this regard, the existing procedures for accommodation of arbitration proceedings provide a helpful analogy. In Spielberg Manufacturing Co. ${ }^{94}$ the Board held that an arbitrator's decision in a case which involved an arguably unfair labor practice would be respected as long as "the proceedings appear to have been fair and regular, all parties had agreed to be bound, and the decision of the arbitration panel is not clearly repugnant to the purposes and policies of the Act." 95 If an issue of union discrimination has been fully adjudicated in a Title VII judicial proceeding, the General Counsel should decline to exercise jurisdiction over a complaint based on the same charge. Because of the issue's resolution in a federal court, the Board could safely assume that fair procedures were followed and that its independent interest in the litigation of union discrimination questions has been satisfied. If the earlier case was tried by the Justice Department, it is even arguable that collateral estoppel would prevent the Board from relitigating the issues resolved. ${ }^{96}$ The same policy should be followed when a complaint has been settled under EEOC guidance, to ensure that the Board does not undermine EEOC settlement efforts.

93. The Interagency Staff Coordinating Committee now in operation was formed in July, 1969 and includes representatives of the Justice Department, Equal Employment Opporturity Commission and Labor Department. Id. at 404.

94. 112 N.L.R.B. 1080 (1955).

95. Id. at 1082.

96. The question of collateral estoppel in regard to administrative determinations is a highly sophisticated one, complex enough to justify treatment in a separate article. See Project, Federal Administrative Law Developments-1969, 1970 Duke L.J. 67, 133-46; Note, Res Judicata and Administrative Jurisdiction-A Proposal for Resolving Conflicts Between Agencles With Overlapping Jurisdiction, 35 Geo. WASH. L. Rev. 1056 (1967); Note, The Applicability of Res Judicata and Collateral Estoppel to Actions Brought Under Section 8(b)(4) of the National Labor Relations Act, 67 Mick. L. REv. 824 (1969). The Supreme Court, however, has recently made it clear that collateral estoppel does apply to administrative determinations wherc appropriate. United States v. Utah Constr. \& Mining Co., 384 U.S. 394 (1966). Professor Davis has argued that res judicata and collateral estoppel have applicability in the administrative law context, but that the normal rules may require serious qualification in this area because of the different roles played by courts and administrative agencies. K. Davis, ADMINISTRATIVE LAW TREATISE $\S 18.03$ (1958). It is questionable whether collateral estoppel will be given much impact in regard to cases under the NLRA and Title VII which are first brought under one statute and then filed under the other. See Tipler v. E.I. duPont deNemours \& Co., 443 F.2d 125 (6th Cir. 1971). The legislative history and language of the two statutes are sufficiently different to make it probable that a majority of courts would not treat the resolution of most issues under one as collateral estoppel under the other. See K. DAvIs, supra $\S$ 18.04. In the typical situation, moreover, there would be different parties in the two cases 
Where arbitration is imminent in a case, the Board generally declines to assert jurisdiction until the proceeding has been completed and the decision can be reviewed under its Spielberg standards. ${ }^{97}$ Similarly, it ought to defer action on a case alleging minority discrimination when a charge has previously been filed before the EEOC. In such a situation, the EEOC's own investigators would be working on the case, state civil rights officers may also be involved, ${ }^{98}$ and there is no reason why the union charged with discrimination should have to deal with a small mob of investigating authorities. Although some burden should probably be placed on the individual to select his own remedy, one who becomes dissatisfied with EEOC procedures and chooses to withdraw his charge should be able to get action from the NLRB. Either alternative would offer some advantages. Most cases would undoubtedly continue to be filed under Title Vll since law and precedent are much better established under that statute. The NLRB procedures, however, ought to be available as an alternative option to the litigant who cannot afford private enforcement or who simply desires public adjudication of his rights..$^{99}$

It is appalling that actions under Title VII now terminate in ninety percent of the cases in which EEOC is unable to obtain private settlement. ${ }^{100}$ Hopefully, as the NLRB's role becomes better established, individuals will seek public enforcement of their rights from the Board in such situations rather than abandon their

since the prosecuting party under the NLRA would be the General Counsel whereas the plaintiff under Title VII would be a private individual. However, federal officers are treated for collateral estoppel purposes as being in privity with each other. Sunshine Anthracite Coal Co. v. Adkins, 310 U.S. 381 (1940). Therefore, if the Title VII case were tried by the Justice Department and the NLRA case by the General Counsel in a situation where the factual issue was precisely the same-for instance, whether a union engaged in racial discrimination-it is arguable that collateral estoppel would apply.

97. Dubo Mfg. Co., 142 N.L.R.B. 431 (1963); Ordman, The Arbitrator and the NLRB, Proceedings of the 20th ANNuAl Meeting, National ACAdemy of ARbitrators 47, 56 (1967). See also Wollett, The Agreement and the National Labor Relations Act: Courts, Arbitrators and the NLRB - Who Decides What?, I4 LAB. L.J. 104 I, 1043 (1963).

98. In any state which has a law prohibiting job discrimination, the EEOC is required to turn the complaint over to state authorities for 60 days. 42 U.S.C. $\$ 2000$ e-5(b) (1964). Generally, state and EEOC investigations go on concurrently after that time. Developments-Title VII 1109, 1215.

99. In order to comply with the statute of limitations under the NLRA, this would necessitate filing of charges with both agencies within six months of the incident which was the basis for the complaint. In this situation, however, the NLRB could delay action on the charge until the EEOC had exhausted its efforts. After the individual had waived his right to sue in court under Title VII, the General Counsel could proceed with action on the charge.

100. See note 82 supra and accompanying text. 
grievances entirely. ${ }^{101}$ In light of Title VII's severe defects, to deprive the Board of its power in this area would be a serious mistake. Moreover, it would leave the Board in an undesirable, anomalous posture-enforcing the rights of white males to fair treatment from their unions while rejecting complaints by blacks, females and other minority workers. ${ }^{102}$

\section{Statutory Analysis of NLRA-Potential For Unfair Labor Practice Findings Against Discriminatory Unions}

The policy favoring a Board role in this area is the same as the policy behind the Steele decision-the constitutional necessity that the government, as the source of union power over minority workers, provide protections against the abuse of that power. ${ }^{103}$ The Court, noting the absence of any possible administrative remedy in Steele, offered the judiciary as a forum to give at least minimal protection to employee rights. Because of the possibility of an administrative remedy after the passage of Taft-Hartley, the Board has begun to play a role in this area in order to give effective implementation to those rights. One could argue against this position on the basis that

101. The scheme proposed here is intended as a possible suggestion for achieving an accommodation between the two statutes. It certainly could require change and refinement. However, given the realities of Title VII's failures in this area, it is a far more desirable solution than the NLRB's total abandonment of its unfair labor practice role in minority discrimination cases, a suggestion made elsewhere. See note 15 supra and accompanying text. A similar method of NLRB accommodation could be achieved in rclation to other means of attacking employment discrimination-judicial suit based on the theory of fair representation or suit under 42 U.S.C. $\$ 1981$ (1964).

102. A bill is once again before Congress to grant the Equal Employment Opportunity Commission enforcement powers. H.R. 1746, 92d Cong., Ist Sess. (1971); see H.R. REP. No. 238, 92d Cong., Ist Sess. (1971). For prior efforts to obtain these powers, see note 9 supra and accompanying text. The bill, however, is opposed by the Administration. 76 BNA LAB. REL. REP. 184 (1971). Even if this bill passes, the NLRB should continue to play a rolc in this area. In its new version, the EEOC would have enormous responsibilities-taking over the enforcement of equal employment rights on all government contract work from the Ofice of Federal Contract Compliance in addition to its present overwhelming work load. Most of this work would involve discrimination by employers. In such a situation it would still be highly desirable to have another federal agency available to deal with discrimination by labor unions. Moreover, the EEOC is always subject to very significant political pressures and is vulnerable because it operates in a heated arena. It is directly tied to Congress' purse strings and is subject to considerable political immobilization. Given such dangers, it is highly desirable that there be an alternative forum to which victims of discrimination may turn for an adjudication of their rights. This is not the type of area which necessarily requires one comprehensivc, sophisticated and uniform system of regulation such as the regulation of communication by the Federal Communications Commission. Rather, the major need is to remedy individual instances of discrimination, and there is no reason why this should not be accomplished by different agencies with diverse approaches.

103. See notes 16-32 supra and accompanying text. 
Congress failed to explicitly make such union discrimination an unfair labor practice. ${ }^{104}$ Despite this lack of express language, however, a persuasive argument can be made that two of the TaftHartley provisions empower the Board to reach such a result.

$8(b)(I)(A)$. Section $8(b)(1)(A)$ makes it an unfair labor practice for unions to "restrain or coerce" employees in the exercise of their section 7 rights. ${ }^{105}$ The Board has held that unions which engage in discrimination against minority employees violate this section, ${ }^{106}$ and the Supreme Court has made the union's fair representation obligation to employees a part of the Act. ${ }^{107}$ The Court has explicitly read the duty into section 2 of the Railway Labor Act which contains language practically identical to section $7 .{ }^{108}$ It therefore seems logical to assume that section 7 of the NLRA, in giving employees the right "to bargain collectively through representatives of their own choosing," includes not only their right to elect a union to bargain for them but also their right to be fairly represented by it. A union which discriminates against a class of employees is "restraining" them in their section 7 right to fair representation and therefore violating $8(\mathrm{~b})(\mathrm{I})(\mathrm{A}) .^{109}$

While it is true that Congress did not make the right to fair representation explicit in section 7 , the Board appears to have sufficient authority to find that the right exists there. The section is written in very broad language, and has always been interpreted by the Board according to its judgment as to how best to achieve the purposes of the Act in the realities of industrial life. On a literal level, for example, the section, by giving employees the "right to selforganization" coupled with $8(a)(1)$ which prohibits all employer

104. See Molinar, The National Labor Relations Act and Racial Discrimination, 7 B.C. IND. \& COMM. L. REv. 601 (1966), where the author argues that what the Board has done in regard to $8(\mathrm{~b})(\mathrm{I})(\mathrm{A})$ generates a "suspicion of [improper] creativity." Id. at 602.

105. Labor Management Relations Act (Taft-Hartley Act) § 101, 29 U.S.C. $\S 158(b)(1)(A)(1964)$.

106. See note 3 supra.

107. Ford Motor Co. v. Huffman, 345 U.S. 330, 337 (1953); see Syres v. Oil Workers Local 23, 350 U.S. 892 , rev'g per curiam, 223 F.2d 739 (1955).

108. Steele v. Louisville \& Nashville Ry., 323 U.S. 192, 199 (1944). Section Two, Fourth of the RLA provides in part:

Employees shall have the right to organize and bargain collectively through representatives of their own choosing. The majority of any craft or class of employees shall have the right to determine who shall be the representative of the craft or class for purposes of this chapter. 45 U.S.C. \& 152 (Fourth) (1964).

109. An alternative argument for finding the duty in section 7 was made by Sovern, Race Discrimination and The National Labor Relations Act: The Brave New World of Miranda, N.Y.U. SIXTEENTH ANNUAL CONF. ON LABOR 3, 10-12 (1963). 
"interferences" with section 7 rights, would seem to prohibit all such interferences. ${ }^{110}$ However, the Board has interpreted that section to permit employer interferences which are justified by the employer's right to run an efficient business operation. "II Similarly, though the section seems to protect all employee activities for the purpose of collective bargaining, the Board has established an exception for activities which are inappropriate, disloyal to the employer, or unlawful under other legal provisions. ${ }^{112}$ The Board's general approach to section 7 was approved and well-summarized by the Court in Republic Aviation Corp. v. NLRB: ${ }^{113}$

The Wagner Act did not undertake the impossible task of specifying in precise and unmistakable language each incident which would constitute an unfair labor practice. On the contrary, that Act left to the Board the work of applying the Act's general prohibitory language in the light of the infinite combination of events which might be charged as violative of its terms. "11

The Board's use of its discretion in making a violation of the duty of fair representation an unfair labor practice thus appears to be well founded, for it is enforcing a right which the Supreme Court has already read into the Act. Additional support for this position comes from the Preamble of the Taft-Hartley Act which states that it was a part of the legislative purpose "to protect the right of individual employees in their relations with labor organizations." 115

There are two possible bases for attacking this argument. One critic of the Board's $8(\mathrm{~b})(1)(\mathrm{A})$ theory has noted that $8(\mathrm{a})(1)$ makes it an unfair labor practice for employers to "interfere with, restrain or coerce" employees in their section 7 rights, whereas $8(\mathrm{~b})(1)(\mathrm{A})$ makes it an unfair labor practice only for unions to "restrain or coerce" employees in the exercise of those rights. From this, it is suggested that the Board has less authority to make union behavior illegal under $8(\mathrm{~b})(1)(\mathrm{A})$ than it has in dealing with employers under $8(\mathrm{a})(1) .{ }^{116}$ However, the legislative history of $8(\mathrm{~b})(1)(\mathrm{A})$ indicates that

110. B. Meltzer, Labor Law, Cases, Materials and Problems 124 (1970).

111. See, e.g., Peyton Packing Co., 49 N.L.R.B. 828, 843 (1943), enforced, 142 F.2d 1009 (5th Cir.), cert. denied, 323 U.S. 730 (1944).

112. NLRB v. Local 1229, IBEW, 346 U.S. 464 (1953) (disloyal activities); Southern Steamship Co. v. NLRB, 316 U.S. 31 (1942) (mutinous activities); NLRB v. Fansteel Metallurgical Corp., 306 U.S. 240 (1939) (unlawful sit-down strike); Elk Lumber Co., 91 N.L.R.B. 333 (1950) (partial work stoppage). See also Getman, The Protection of Economic Pressure by Section 7 of the National Labor Relations Act, 115 U. PA. L. REv. 1195 (1967).

113. 324 U.S. 793 (1945).

114. Id. at 798.

115. Labor Management Relations Act (Taft-Hartley Act) § 1, 29 U.S.C. § 141 (1964).

116. See Molinar, supra note 104, at 607-08. 
the words "interfere with" were dropped solely in deference to the fears of one Senator that the section might otherwise be interpreted to make peaceful persuasion of employees by unions illegal. ${ }^{177}$ For purposes of the right to fair representation, the word "restraint" is virtually synonymous with the word "interfere." "Restrain" is defined as "to hold back from action, check, curb, limit and restrict." "118 Employees are clearly "held back, checked, curbed, limited and restricted" from the full realization of their section 7 rights by the union's failure to represent them fairly.

The second attack comes from the dissenting Board members in Miranda by their strong emphasis on the Supreme Court decision in NLRB v. Drivers Local 639.19 The potentially troubling aspect

117. On April 25, 1947, Senator Ives of New York objected to the term "interfere with" as applied to labor unions in the original version of the section for the following reasons:

Let us consider the words "interfere with." How is a labor organization or anyone, trying to persuade others to join a labor organization, to operate, under the possible interpretation of the words "interfere with?"' If I, belonging to a union, were to sit down and try to talk with the Senator from Delaware [Mr. Buck] . . . and if I were to say to him that I think he should join, . . . doing my utmost to make a persuasive appeal, perhaps the Senator would not like some feature of my appeal. Possibly somebody might stir him to anger . . . and cause him to decide to challenge what 1 was trying to do, by going to the Labor Relations Board . . . charging an unfair labor practice because of my interference with what he might consider to be his right. 93 CoNG. REC. 4020 (1947) (emphasis added).

On May 2, Senator Smith explained the reason for dropping the words "interfere with" from the bill:

I can see nothing in the language used which could possibly be construed as interfering with the right of solicitation of membership, with legitimate rules being laid down as to how members should be solicited.

The words "to interfese with" appear under section $8(a)[8(a)(1)]$, so far as employers are concerned, and on request of the distinguished Senator from New York [Mr. Ives], 2 days ago by unanimous consent we eliminated those words, because we were afraid that they might imply that if a fellow member or an agent did something entirely legitimate, the words "interfere with" might be construed as being sufficiently broad to prevent that happening.

There is no intention whatever to prevent the legitimate building up of a union organization. . . 92 CONG. REC. 4435 (1947).

118. WeBster's New World Dictionary 634 (concise ed. 1964).

119. 362 U.S. 274 (1959). In that case, the Court held that the Board could not use section $8(b)(1)(A)$ to illegalize peaceful recognitional picketing by a union that had been rejected by a majority of the employees in the plant where the picketing was being conducted. On its facts, the case is very clearly distinguishable from our situation. The Court noted that the Board had exceeded its discretion for several reasons. It equated the right to picket with the right to strike and argued that section 13 of the NLRA, 29 U.S.C. \& 163 (1964), prevented the Board from interfering with such rights absent speciffe legislative restrictions. 362 U.S. at 281-82. The Court also argued from its long tradition of protection of peaceful persuasion. Id. at 279. It further noted that it was improbable that Congress intended the Board to regulate these particular activities under section $8(b)(I)(A)$ since it had later passed specific legislation covering the problem. Id. at 282-84, 291-92 (discussing congressional passage of $\S \S 8(\mathrm{~b})(4)$ and $8(\mathrm{~b})(7)$ ). 
of the case is the Court's discussion of the limitations of $8(\mathrm{~b})(1)(\mathrm{A})$, summarized in the following statement from Justice Brennan's opinion:

$8(b)(1)(A)$ is a grant of power to the Board limited to authority to proceed against union tactics involving violence, intimidation and reprisal or threats thereof-conduct involving more than the general pressurcs upon persons employed by the affected employers implicit in economic strikes. ${ }^{120}$

The dissent in Miranda argued that this part of the opinion indicates that the Board's power under $8(\mathrm{~b})(\mathrm{l})(\mathrm{A})$ is too limited to permit its use for fair representation violations. ${ }^{121}$ One commentator has stated that this opinion shows that "active [union] conduct in the nature of physical force or distinct threats of direct economic reprisal" are necessary to have restraint or coercion in violation of the section. ${ }^{122}$ The legislative history does show that union activity involving violence, intimidation and reprisal was a major concern of Congress in passing $8(\mathrm{~b})(1)(\mathrm{A}){ }^{123}$ However, there is also evidence of a broader congressional purpose-to create a greater equivalency in the liabilities of employers and unions under the Act, and thus, to make it more equitable. ${ }^{124}$ Presumably, if Congress had intended to apply

120. 362 U.S. at 290.

121. 140 N.L.R.B. at 201.

122. Molinar, supra note 104, at 608.

123. Senator Taft in advocating the passage of $8(\mathrm{~b})(\mathrm{I})(\mathrm{A})$ made the following statement:

Why should a union be able to go to an employee and threaten violence if he does not join the union? Why should a union be able to say to an employee, "If you do not join this union we will see that you cannot work in the plant . . . ?" We know that such things have actually occurred. We know that men have been threatened. 93 CoNG. Rec. 4021 (1947).

The report of supplemental views which announced the intention of five Senators to propose the amendment stated their concern that the Act illegalize union violence, coercion and threats of reprisal against employees and their families in the course of organizing campaigns. S. REP. No. 105, 80th Cong., Ist Sess. 50 (1947). Arguing in support of the amendment, Senator Ball cited numerous examples of organizing drives characterized by violence, job reprisals and union repression. 93 CoNG. Rec. 4016-17 (1947).

124. Statements by Senator Taft:

It seems to me that a perfectly clear case of necessity exists to include this amendment if we wish to secure the equality which the bill aims to give as between employers and employees. The present law expressly provides, and has provided for many years, that it is an unfair labor practice for any employer to interfere with, restrain, or coerce employees in the exercise of the rights guaranteed in section 7. This amendment proposes to say that it shall also be an unfair labor practice for an employee organization, $a$ union or its agents, to interfere with, restrain, or coerce employees in the exercise of rights guaranteed in Section 7.93 CoNG. Rec. 4021 (1947) (emphasis added).

[I]t is believed that if we retain the unfair labor practice procedure against employers, an effort should be made to bring about some measure of equality by defining unfair labor practices on the part of labor unions ..... I see no reason to think it is any more difficult for the unions than it is for the employer. . . . Id. at 4436. 
$8(b)(1)(A)$ to only "violence, intimidation and reprisal," it would have specifically indicated that purpose, rather than applying it to any "restraint" of section 7 rights. In a subsequent case, the Court has held $8(\mathrm{~b})(1)(\mathrm{A})$ applicable to a situation where the union was not engaged in the use of force or threatening conduct. ${ }^{125} \mathrm{~A}$ proper reading of Justice Brennan's remarks, and the Court's opinion in Drivers Local 639 should be directed at the context in which they were written-the use of $8(\mathrm{~b})(1)(\mathrm{A})$ in union organizational efforts. The case, and Justice Brennan's statement, demonstrate the Court's concern, heavily supported by the legislative history of TaftHartley, ${ }^{126}$ that the section not be used as a weapon to impede peaceful persuasion. Only in that situation was $8(b)(1)(A)$ held to be limited to violent or intimidating union action. A proper reading of the case indicates in context that it is not concerned with union behavior after organization has been successful, and thus offers no obstacle to the view that an elected union which unfairly represents minority workers violates $8(\mathrm{~b})(1)(\mathrm{A})$.

$8(b)(2)$. Section $8(b)(2)$ makes it illegal for a union to cause or attempt to cause an employer to violate section $8(\mathrm{a})(3)$ by discriminating "in regard to hire or tenure of employment or any term or condition of employment to encourage or discourage membership in any labor organization." ${ }^{227}$ The Court has interpreted these sections broadly to prohibit any encouragement of union activity or performance of union obligation by discrimination. ${ }^{128}$ Although in Miranda ${ }^{129}$ the Board held that a union which causes an employer to discriminate against a minority employee violates $8(b)(2)$, the dissenting Board members and the second circuit ${ }^{130}$ disagreed, maintaining that $8(b)(2)$ prohibits only discrimination based upon a man's union membership or other union-connected activities, not discrimination based on race or sex or some other nonunion related ground. ${ }^{131} \mathrm{lt}$ is argued that this is a section designed to "insulate employee jobs from their organizational rights" 132 - to

125. IL.GW v. NLRB, 366 U.S. 731 (1961). The union was held guilty of a violation of $8(b)(1)(A)$ for restraining employees' section 7 rights by signing a contract with the employer in the mistaken belief that it represented a majority of his employees.

126. Molinar, supra note 104 , at 608 .

127. 29 U.S.C. $\$ \S 158(a)(3),(b)(2)(1964)$.

128. Radio Officers v. NLRB, 347 U.S. 17, 39-42 (1953).

129. 140 N.L.R.B. 181 (1962).

130. NLRB v. Miranda Fuel Co., 326 F.2d 172, 175-76 (2d Cir. 1963).

131. 140 N.L.R.B. at 193-99.

132. Radio Officers v. NLRB, 347 U.S. 17, 40 (1953). 
prevent an employee from being punished in his job for failing to join a union or for some delinquency in his union obligations. Thus, if an employee is discriminated against for a reason having to do with his union status, the section is violated. Otherwise, it is not.

A careful analysis of Court decisions interpreting 8(a)(3), however, indicates that there is strong support for the Board's view. In a typical case under the section, the Court required a showing of "scienter" or wrongful motive-that the employer and/or the union discriminated with the intent to encourage improved union status. ${ }^{133}$ Though this is the general rule, there are two special situations where specific evidence of "bad motive" is not necessary. In these circumstances the Board balances the harm to employee rights, which occurs as a result of employer and union discriminatory conduct, against the justification for such conduct. ${ }^{134}$

The first exception concerns a situation where the employer's discrimination has an especially severe impact in encouraging or discouraging union activity, which considerably outweighs the business justification that the employer offers. In such a case, the employer is held responsible for violating the section whether or not a showing of specific wrongful intent is made, since the results of insufficiently justified discrimination could have been foreseen. He is, therefore, held responsible for having intended them. ${ }^{135}$ The second exception was established in NLRB v. Great Dane Trailers, ${ }^{136}$ where the Court held that if there is discrimination which could result in some discouragement or encouragement of union activity and there is no offer of a legitimate and substantial business justification, the employer will also be held responsible for violating the section without specific proof that he intended such a result.

The Great Dane doctrine applies very well to the equal employment situation. If a union causes an employer to discriminate against an employee on the basis of the latter's race or sex, this

133. Id. at $42-44$.

134. In NLRB v. Erie Resistor Corp., 373 U.S. 221 (1963), the Court said, in discussing this siluation:

The ultimate problem is the balancing of conflicting legitimate interests. The function of striking that balance to effectuate national labor policy is often a difficult and delicate responsibility which the Congress committed primarily to the National Labor Relations Board, subject to limited judicial review. Id. at 236.

135. Id. at 227. Thus, in Erie Resistor, the Court held that an offer of super-seniority to striker replacements was unlawful, under the theory discussed in text. Id. at 231 .

136. 388 U.S. 26 (1967). In this case, the Court held that a grant of vacation pay only to non-strikers violated the Act because of the failure of the employer to offer any legitimate and substantial business justification for the discrimination against strikers. Id. at 35 . 
conduct would seem to constitute "discrimination" within the meaning of $8(a)(3)$. Despite the argument of the dissenting Board members in Miranda, the section does not say that the discrimination with which the section is concerned must be on the basis of union status; it simply uses the term "discrimination"-that is, distinction or differentiation without sufficient reason. ${ }^{137}$ Job distinctions based on race, ethnic origin or sex, unless the latter is a bona fide occupational requirement, lack sufficient justification and come within the term "discrimination" in 8(a)(3). Moreover, under the Great Dane rationale, such discrimination could very well "encourage union membership" or activity. The evidence of successful use of arbitrary union power will make other employees fearful of what the union may do to them in their employment status if they fail to "toe the union line." Thus, they will be encouraged to join the union, bow to the union's authority, and remain in good union status in order to preserve their jobs. This has the effect of undermining the section's purpose of assuring employees that their job status is independent of their union status. Following Great Dane, it is not necessary that there be specific evidence that the employer or union intended this result, so long as some possibility of adverse impact on employee rights was reasonably foreseeable and the employer and union fail to come forth with any substantial and legitimate justification for their conduct. It is hard to imagine what legitimate objectives the employer or union could offer for having engaged in racial, religious, ethnic or sex discrimination. Thus, we would have discrimination which encouraged union membership under the Court's interpretation of $8(b)(2)$ and $8(a)(3)$, and such union and employer conduct would, therefore, be in violation of those sections. ${ }^{138}$

\section{Scope of the Miranda Doctrine in Equal Employment Cases}

It will be recalled that in Miranda the Board held that a union which caused an employer to discriminate against a worker had

137. NLRB v. Miranda Fuel Co., 326 F.2d 172, 181 (2d Cir. 1963) (Friendly, J., dissenting). Although much of the analysis which follows is discussed in Judge Friendly's opinion in Miranda, it does not discuss the problem in the context of Great Dane which appeared four years later.

138. The $8(b)(2) / 8(a)(3)$ theory is only useful as an alternative ground in a situation where the union is responsible for causing the employer to discriminate or where the two are working actively in collusion to discriminate against minority workers. The theory is probably inappropriate where the union is violating its duty of fair representation by passively accepting employer discrimination while failing to work actively for the interests of minority employees. In such cases, the union is not "causing" or attempting to cause the employer to discriminate 
committed an unfair labor practice. ${ }^{139}$ Since any union treatment of an employee on the basis of his minority status involves the use of an "unfair, irrelevant and invidious" factor, 140 the scope of the Board's Miranda doctrine is similar to the scope of Title V11.141 In each case the Board must decide whether the union has treated the complainant on the basis of his race, sex, religion, or national origin. The doctrine extends to any discrimination in the negotiation of the collective bargaining agreement, ${ }^{142}$ in its administration, ${ }^{143}$ or in the union's treatment of minority grievances. ${ }^{144}$

In Metal Workers Local I [Hughes Tool Co.], ${ }^{145}$ the dissenting Board members argued that this doctrine would lead to excessive

since he has instituted the discrimination himself. Reliance on cases of this type should be placed upon $8(\mathrm{~b})(\mathrm{I})(\mathrm{A})$. The Board has found $8(\mathrm{~b})(2)$ violations in two cases where the union refused to prosecute employee grievances. Local No. 12, URW [Business League of Gadsden], 150 N.L.R.B. 312 (1964); Metal Workers Local 1 [Hughes Tool Co.], 147 N.L.R.B. 1573 (1964). A proper reading of the statute does not, however, support these findings.

The Board also utilizes section $8(b)(3)$ of the Act in these cases, arguing that unions which unfairly represent workers are violating their $8(b)(3)$ obligation to bargain in good faith. Local 12, URW, supra; Metal Workers Local 1 [Hughes Tool Co.], supra. However, the statutory language and legislative history of the section appear to contradict this view. Unlike $8(\mathrm{~b})(1)(\mathrm{A})$ and $8(\mathrm{~b})(2)$ the union's obligations under 8(b)(3) appear to run directly to the employer rather than to the employees. The section itself is written entirely in reference to the union-employer relationship-

(b) It shall be an unfair labor practice for a labor organization-

....

(3) to refuse to bargain collectively with an employer ...

The duty to bargain is defined in section $8(d)$ as the mutual obligation of the employer and the union to meet at reasonable times and confer in good faith. Finally, the legislative history indicates that the section was designed to place upon the union the same obligation to bargain with the employer that the employer already had in relation to the union. See Joint Congressional Study Committee on Labor Relations, 80th Cong., Ist Sess., REPORT ON Federal Labor Relations ACT of 1947, 22 (Statement by Senator Taft, 1947). See also Sovern 170. However, a unjon which insisted upon a discriminatory demand in negotiations in the face of employer opposition might very well violate the section by insisting to the point of impasse on a non-mandatory, illegal clause. SOVERN 170. Cf. NLRB v. BorgWarner Corp., 356 U.S. 342 (1957).

139. See notes 26-32 supra and accompanying text.

140. 140 N.L.R.B. at 185 (1962).

141. While it is not suggested here that the preedents decided under Title VII would be absolutely applicable to NLRA cases, they may have considerable relevance by analogy. Title VII of the Civil Rights Act of 1964, 42 U.S.C. $\S \S 2000$ e to -2 (c)(1) (1964) also prohibits discrimination in union membership policies. Such discrimination has not been made an unfair labor practice under the NLRA; however, it may lead to the Board's refusing to certify a union, rescinding a union's existing certification, and withdrawing the Act's other protections. See SOVERN $156 \cdot 60$.

142. Steele v. Louisville \& Nashville R.R., 323 U.S. 192 (1944).

143. 140 N.L.R.B. 181 (1962).

144. 147 N.L.R.B. 1573 (1964).

145. Id. 
interference with the discretion of unions and to the Board's sitting in judgment on the substantive matters of collective bargaining, a practice the Court has specifically condemned. ${ }^{146}$ In the minority discrimination context, however, that argument is specious. The union's right to exercise discretion in selection of economic weapons ${ }^{147}$ and bargaining strategy, ${ }^{148}$ and to make relevant differences in contract bargaining among the employees it represents, ${ }^{149}$ cannot be equated with a right to engage in racial, religious or sex discrimination. ${ }^{150}$ Although fair representation decisions have recognized the union's considerable latitude in making judgments based on economic factors, ${ }^{151}$ it is possible for the Board to pay considerable deference to that discretion and still prohibit union discrimination. If it finds that a union decision is based on differences in skill, experience or any other relevant factors, Miranda would not permit the Board to substitute its judgment for the union's. Insofar as the decision was based on the employee's minority status, however, the Board could find an unfair labor practice. By enforcing this limitation on the union's discretion, the Board is clearly acting consistently, not in opposition, with the Court's interpretation of the Act.

In remedying an unfair labor practice, the Board is authorized to take "such affirmative action ... as will effectuate the policies of the [Act]." 152 In individual instances of discrimination, the orders might simply require the unions to terminate their discrimination, ${ }^{153}$ give active representation to minority employees, ${ }^{154}$ or pay damages to victims of union discrimination who lose work opportunities. ${ }^{155}$ The Board's remedial power is also sufficiently broad to permit more

146. Id. at 1589-90.

147. NLRB v. Insurance Agents Int'l Union, 361 U.S. 477 (1960).

148. See generally NLRB v. Wooster Division of Borg-Warner Corp., 356 U.S. 342 (1958);

NLRB v. American Nat'l Ins. Co., 343 U.S. 395 (I951).

149. See Ford Motor Co. v. Huffman, 345 U.S. 330, 337-38 (1945).

150. To the extent that the union's discretion is limited in this regard, the limitation has been stated as follows:

[T] he statutory power to represent a craft and to make contracts as to wages, hours and working conditions does not include the authority to make among members of the craft discriminations not based on such relevant differences .... [D]iscriminations based on race alone are obviously irrelevant and invidious. Steele v. Louisville \& Nashville R.R., 323 U.S. 192, 203 (1944).

151. See Ford Motor Co. v. Huffman, 345 U.S. 330, 337-38 (1945).

I52. National Labor Relations Act \& 10(c), 29 U.S.C. \& I60(c) (1964).

153. Local 12, URW [Business League of Gadsden], 150 N.L.R.B. 312, 323 (1964).

154. Id.

155. Houston Maritime Ass'n, 168 N.L.R.B. 615,619 (1967). 
imaginative remedies in cases of extensive union discriminatory practices. Thus, it can decertify a discriminating union thereby depriving the union of the Act's other protections. ${ }^{156}$ Moreover, it is probably authorized to order major changes in union hiring hall systems and alterations in a plant's seniority system ${ }^{157}$ to effectuate the Act's policies by removing the present effects of prior discrimination. In this respect, the Board's remedial powers would appear to be very similar to those of federal district courts operating under Title VII. ${ }^{158} \mathrm{~A}$ number of innovative Title VII remedial measures recently adopted by the courts appear to be equally appropriate for NLRA violations. ${ }^{159}$

\section{Discrimination Against Minorities As Employer UnFair Labor PRACTICES}

\section{Joint Employer Liability ${ }^{160}$ in Union Discrimination Cases}

The NLRA also has considerable potential as a weapon against employer discrimination in unionized plants. When a union makes a discriminatory demand and the employer goes along with the union

156. See cases cited in note 32 supra. See also SoverN 156-60.

157. The General Counsel has issued an unfair labor practice complaint against a union hiring hall in an effort to force it to keep job applicants regularly informed of work opportunities. 76 BNA LAB. REL. REP. 107 (1971). The Board could require that such information be given to minority job applicants as part of its remedy.

To invoke such a remedy, it might be necessary to secure jurisdiction over the employer by a finding that the employer was jointly liable for an unfair labor practice because of his involvement in the union discrimination. See notes 160-65 infra and accompanying text.

158. The Board's powers may be broader than judicial authority under Title VII because of the special limiting provisions in the latter statute under 42 U.S.C. $\$ \S 2000 \mathrm{e}-2(\mathrm{~h}),(\mathrm{j})$ (1964).

159. In Insulators Local 53 v. Vogler, 407 F.2d 1047, 1051, 1055 (5th Cir. 1969) the remedial order under Title VII required alternating black and white referrals for work. In several other decisions, the courts have required considerable changes in existing seniority systems to remove the present effects of prior discrimination. Dobbins y. Electrical Workers Local 212, 292 F. Supp. 413 (S.D. Ohio 1968); United States v. Papermakers Local 189, 282 F. Supp. 39 (E.D. La. 1968), affd, 416 F.2d 980 (5th Cir. 1969), cert. denied, 397 U.S. 919 (1970); Quarles v. Phillip Morris, Inc., 279 F. Supp. 505 (E.D. Va. 1968).

In a speech before the Colorado Bar Association on May 13, 1971, the National Labor Director of the NAACP called on the Board to disestablish discriminating unions. He argued that the Board's constitutional responsibilities require that it go beyond anything it has done thus far. 77 BNA LAB. REL. REP. 88, 93-94, 95-96 (1971).

160. Dean Sovern, discussing this problem, uses the term "derivative" employer liability. SOVERN 154. I use the term "joint employer liability" because I believe that the designation, derivative liability, may imply that the employer's responsibility must arise out of a prior discriminatory act by the union. As argued in the text, I believe that there are possibilities for the employer's being jointly liable with the union even when he instigates the discrimination himself. 
request, the Board has found that he has committed a derivative unfair labor practice. ${ }^{161}$ For example, if the employer complies with a union request to place arbitrary limits on the advancement of female employees, he has violated $8(a)(1)$ by cooperating with the union and thereby contributing substantially to the interference with the rights of female workers to fair representation. He has also violated 8(a)(3) under the $8(\mathrm{~b})(2) / 8(\mathrm{a})(3)$ theory ${ }^{162}$ since it is the employer's act of discrimination caused by the union against which these sections are ultimately directed.

A somewhat more difficult question arises in a situation where the employer establishes discriminatory working conditions and the union fails to resist them. Assume, for instance, that the employer refuses arbitrarily to promote female employees above a certain level and the union fails to actively oppose the discrimination. The $8(b)(2) / 8(a)(3)$ theory clearly is inapplicable since it cannot be said that the union has "caused" the employer to discriminate. A strong argument can be made, however, that here, also, the employer has violated $8(a)(1)$ because he and the union are jointly and inextricably implicated in the wrong which has been committed. The employer has in such a case contributed substantially to the interference with the employee's section 7 rights to fair representation by creating the conditions under which the union discrimination occurred. Moreover, since the employer and union jointly negotiate and administer the collective bargaining agreement, it would probably be impossible in most cases to separate one's responsibility from the other's. ${ }^{163}$ As long as both are acting arbitrarily, each is supporting the other's conduct and they should be held jointly responsible. The Board seems to be leaning in the direction of reaching this result. ${ }^{164}$

This conclusion is highly desirable because of the need to fashion

161. 140 N.L.R.B. 181 (1962). See Richardson v. Texas \& New Orleans R.R., 242 F.2d 230,236 (5th Cir. 1957) in which employer liability was found in a duty of fair representation derivative suit.

I62. See 140 N.L.R.B. 18 I (1962).

163. A perfect example of this is found in the case of Local 12, URW [Business League of Gadsden], 150 N.L.R.B. 312 (1964). The collective bargaining agreements never contained discriminatory clauses over a period of twenty years. Nevertheless, through covert employer and union cooperation, the plant had racially segregated dining, toilet and recreation facilities, and employment opportunities were divided into "white" jobs and "black" jobs. There was no possible way to allocate responsibility for the discrimination between the employer and union other than to say that both were seriously implicated.

164. See id. at 316 where a union was found to have arbitrarily failed to negotiate fairly for Negroes or prosecute the grievances of black workers. There, the Board stated:

The Company has an additional duty under the Act, which it apparently overlooked, 
meaningful remedies for union discrimination in such cases. The Board would be seriously limited in its remedial powers if it could issue orders only against the union. It could order the union to actively pursue an employee's grievance or pay damages for work opportunities which the employee loses as a result of the union's failure, but the former may be an unrealistic remedy in light of the union's past hostility or indifference toward the employee. Moreover, by the time the Board issues its remedy, it may be too late for active representation to be meaningful. Also, damages may not provide adequate relief. By finding the employer liable, however, the Board can assume jurisdiction over him and issue affirmative relief requiring reinstatement and promotions in appropriate situations. ${ }^{165}$

This theory has wide implications because it would make any employer discrimination against minorities in a unionized plant a potential unfair labor practice. It should serve primarily to give the Board meaningful power to deal with union discrimination. Its applicability, however, should be limited to situations in which it is first proven that the union has violated its duty of fair representation. Unless such a showing is made, there would be no basis for finding employer liability on the theory of joint inteference with employee rights. Instead, consideration would have to be given in such cases to one of the possibilities for independent employer liability.

\section{Independent Employer Unfair Labor Practices}

The major developments regarding the Board's role in the equal employment area in recent years have occurred in cases in which the sole issue was employer discrimination where no questions of union complicity were raised. These cases have created the possibility of the Act's becoming a full-fledged equal employment statute, equally usable against employers and unions. In analyzing the problems in this area, it is important to note that by treating the NLRA in terms

not to enter into or accept the benefits of discriminatory agreements with the Respondent [union].

The Board then cited the following statement from Richardson v. Texas \& New Orleans R.R., 242 F.2d 230, 236 (5th Cir. 1957):

It takes two parties to reach an agreement, and both have a legal obligation not to make or enforce an agreement or discriminatory employment practice which they cither know, or should know, is unlawful. Unless financial responsibility for a joint breach of such duty is required from both sides of the bargaining table, the statutory policy implied under Steele will be impracticable of enforcement. For the foregoing rcasons, we think the Brotherhood's obligation under the statute does not exist in vacuo, unsupported by any commensurate duty on the part of the carrier.

165. See Richardson v. Texas \& New Orlcans R.R., 242 F.2d 230, 235-36 (5th Cir. 1957). 
of its own language, legislative history, and administrative and judicial development, the Act has special limitations which are not present in civil rights statutes.

Much of the argument favoring a vigorous role for the Board in union discrimination cases is based on the Board's special constitutional responsibilities in that area. ${ }^{165}$ It is useful, therefore, to ask whether similar constitutional questions arise in cases of employer discrimination. To the extent that an employer is cooperating with a union's violation of its duty of fair representation, he may share responsibility for the infringement of his employees' constitutional rights. If he is acting independently, however, his conduct is not subject to constitutional regnlation -it simply cannot be maintained that governmental action or support exists in a case of independent employer discrimination. The NLRA, rather than delegating governmental authority to an employer, takes power from him. Where he previously had authority to establish his own employment conditions-or at least to make his own decision as to whether to deal with a union -the Act's passage narrows his power by forcing acceptance of the union as a joint partner in employment relations decisions. Absent governmental support for discrimination, there is no basis for finding constitutional duty. ${ }^{167}$ Thus, there could not have been a Steele decision in a case of independent employer discrimination, and the Board has no special constitutional responsibility in those situations. Any NLRB involvement in such cases, therefore, must be supported by the more explicit statutory policies of the Act.

Employer Refusal to Bargain When Union Demands Elimination of Discriminatory Working Conditions. In Packinghouse Workers, ${ }^{168}$ the Board held that an employer violates section 8(a)(5) if he refuses to agree to a union request to bargain regarding the elimination of discriminatory working conditions. This result is undoubtedly correct. Such terms clearly fall within the section 8(d) definition of terms requiring mandatory bargaining-"wages, hours, and other terms and conditions of employment." 169 In the interest of public policy, the Board has quite properly given a broad construction to

166. See noles 33-59 supra and accompanying text.

167. See Shelley v. Kraemer, 334 U.S. 1, 13 (1948).

168. Farmers' Coop. Compress (United Packinghouse Workers), 169 N.L.R.B. 290 (1968), revised and aff d, 416 F.2d 1126 (D.C. Cir.), cert. denied, 396 U.S. 903 (1969).

169. National Labor Relations Act § 8(d), 29 U.S.C. \$ 158(d) (1964); see NLRB v. Wooster Div. of Borg-Warner Corp., 356 U.S. 342 (1958). 
what constitutes working conditions in discrimination cases. Thus, $8(a)(5)$ requires bargaining on union request about discrimination in washroom and cafeteria facilities as well as about discrimination in the use of the company golf course. ${ }^{170}$ However, the correct remedy for a violation under $8(a)(5)$ is an order to the employer to discuss these issues with the union-not an order for the removal of the discriminatory conditions. The Board has power under $8(a)(5)$ to order discussion but, as the Court has recently affirmed, ${ }^{171}$ it does not have the power to compel an agreement or require the making of concessions. This limitation on the Board's power is codified in section $8(\mathrm{~d})^{172}$ and expresses a clear congressional policy to protect the employer's right to bargain free from excessive Board interference. The discrimination itself, while violative of Title VII, would not be within the purview of the NLRA.

Employer Interference with Concerted Activities. In addition to protecting organizational and unionization activities, the Act contains a related but independent policy under section 7 which protects employees in other concerted activities for "mutual aid or protection."173 This policy raises the possibility that employer interference with a concerted minority effort to achieve better working conditions will be an unfair labor practice under $8(a)(1)$. Because the Packinghouse theory would have enormous implications in this area, we shall defer consideration of that theory, ${ }^{174}$ and consider first a more traditional interpretation of the NLRA. There are two broad categories of cases in this area. The first concerns employee efforts to improve working conditions for minorities where no union is present. The second relates to situations where an elected union representative is present and the employees choose to act independently of it.

1. Concerted Employee Activities in a Non-Unionized Situation. In Mason \& Hanger-Silas Mason Co., ${ }^{175}$ two black carpenters ${ }^{176}$

170. In Local 12, URW [Business League of Gadsden], 150 N.L.R.B. 312 (1964) the Board held that the union violated its $8(b)(3)$ obligation by failing to bargain with the employer to integrate all of these facilities, arguing that they were all working conditions. Id. at 317-19. If they are working conditions for purposes of $8(b)(3)$, they come within $8(d)$ and are also undoubtedly working conditions under $8(b)(3)$ 's correlative-8(a)(5).

171. In H.K. Porter Co. v. NLRB, 397 U.S. 99 (1970), the Court held that the Board lacked authority to remedy an $8(a)(5)$ violation by ordering a dues check-off provision that the union had requested.

172. National Labor Relations Act \& 8(d), 29 U.S.C. § 158(d) (1964).

173. Id. \& 7,29 U.S.C. \& 157 (1964).

174. See notes 209-25 infra and accompanying text.

175. 79 N.L.R.B. No. 71,72 L.R.R.M. 1372 (1969).

176. The two employees involved were unionized carpenters. It would have been possible 
sought employment from a segregated construction company, informing the job foreman and project manager that they were engaged in an cffort to increase job opportunities for black carpenters in the St. Louis area. Thereafter, the project manager instructed the foreman to hire minority personnel in all craft classifications. The two blacks involved in the initial request were told that no vacancies existed, but within a short time other black carpenters were hired. The Board concluded that these two were discriminated against because of their involvement in a protected effort and ordered the employer to hire them.

This decision is supported by a long line of judicial and Board precedents protecting non-union concerted employee activities. ${ }^{177}$ In general, the rules relating to protection of minority pressures will be the same as those regarding protected activities by other employees. ${ }^{178}$ In New Negro Alliance y. Sanitary Grocery Co., ${ }^{179}$ the Court gave express recognition to the fact that federal labor policies protecting workers involved in "labor disputes" encompass those who are engaged in protests against racial and, presumably, other types of minority job discrimination. Thus, in a typical situation, blacks who were fired for picketing to protest discriminatory promotion policies of their employer would be entitled to reinstatement.

It is important to note, however, that the concern of section 7 is with the protection of the protest - not the elimination of the underlying racial discrimination. Thus, an appropriate remedial order would simply require a return to the status quo before the protestors were fired. If blacks were engaged in menial jobs prior to the firing, the order would require their return to those jobs. The Act's policies would not support an order directing the employer to yield on the question in contention - the fair advancement of blacks to higher-level

for the Board to analyze this case from the same perspective that the Ninth Circuit used in NLRB v. Tanner Livery, Ltd., 419 F.2d 216 (9th Cir. 1969), discussed at notes 197-208 infra and accompanying text. Thus, the Board could have considered the problem of whether the carpenters should have worked through their union in their efforts. Since the Board's opinion did not consider this question, the case is treated here as one dealing only with the general question of the Act's protection of concerted minority efforts to improve working opportunities.

177. NLRB v. Washington AI. Co., 370 U.S. 9 (1962); NLRB v. KDI Precision Prod., Inc., 436 F.2d 385 (6th Cir, 1971); Electromec Design \& Dev. Co. v. NLRB, 409 F.2d 631 (9th Cir. 1969); G \& WV Elec. Spec. Co., is4 N.L.R.B. 1136 (1965).

178. For a comprehensive discussion of these rules, see Getman, The Protection of Economic Pressure by Section 7 of the National Labor Relations Act, 115 U. PA. L. REv. 1195 (1967).

179. 303 U.S. 552 (1938). The case concerned the applicability of Norris La-Guardia protections to picketing against job discrimination. 
positions. As far as the NLRA is concerned, such an order would be comparable to an economic strike situation in which the Board not only required that fired strikers be reinstated but also forced the employer to yield on their demands for higher wages. In both situations, the NLRA requires that the outcome of the question in conflict be determined by a free economic clash. ${ }^{180}$ In this respect, it differs from statutes designed expressly for civil rights purposes where the remedy would include the removal of all elements of job discrimination.

A further distinction between the NLRA and express equal employment statutes lies in the requirement that the employees be involved in "concerted" efforts. Though a single employee certainly can come within section 7's purview, he must be engaged in activity which is designed to induce group action. ${ }^{181}$ Thus, an employee who is fired for complaining about bad employment conditions is unprotected, ${ }^{182}$ while a worker conversing with another for the purpose of stimulating group protest is protected. ${ }^{183}$ Significantly, this means that the simplest and most typical situations covered by other equal employment statutes-an employer's discriminatory act in demoting, discharging or refusing to hire particular employees because of their race or sex-normally falls outside the concern of section 7 because it does not involve a question of concerted employee activities.

The Board has recently decided an interesting case concerning the right of employces to be protected in their efforts on behalf of minority workers of another employer. In Building Service Employees, ${ }^{184}$ a female union organizer was serving outside her regular job as the president of Radical Women, an organization whose function was to improve the status of female employees. The

180. See National Labor Relations Act § 8(d), 29 U.S.C. \& 158(d) (1964): "4o bargain collectively ... does not require either party to agree to a proposal or require the making of a concession." See generally H.K. Porter Co. v. NLRB, 397 U.S. 99 (1970); American Ship Bldg. Co. v. NLRB, 380 U.S. 300 (1965); NLRB v. Insurance Agents Int'l Union, 361 U.S. 477 (1960).

181. Indiana Gear Works v. NLRB, 371 F.2d 273 (7th Cir. 1967); Johanna Cotton Mills v. NLRB, 176 F.2d 749 (4th Cir. 1949). This requirement was defined in Mushroom Transp. Co. v. NLRB, 330 F.2d 683 (3d Cir. 1964) as follows:

[A] conversation may constitute a concerted activity although it involves only a speaker and a listener, but to qualify as such, it must appear at the very least that it was engaged in with the object of initiating or inducing or preparing for group action or that it had some relation to group action in the interests of employees. Id. at 685 .

182. Mushroom Transp. Co. v. NLRB, 330 F.2d at 685.

183. Salt River Valley Water Users Ass'n v. NLRB, 206 F.2d 325 (9th Cir. 1953); NLRB v. Schwartz, 146 F.2d 773 (5th Cir. 1945).

184. 188 N.L.R.B. No. 141, 76 L.R.R.M. 1467 (197I). 
union-employer objected to her activities in this capacity, arguing that they brought disrepute on the union. The organizer was fired when her supervisor saw a newspaper story which reported her arrest in a demonstration against job discrimination. The Board held that she was engaged in a protected activity and ordered her reinstatement.

A long series of Board and court cases supports the view of this case that the terms "concerted activities" for "mutual aid and protection" under section 7 include efforts by employees on behalf of workers of other employers. ${ }^{185}$ The Act explicitly indicates that for labor dispute purposes the term employee is not "limited to employees" of a particular employer, ${ }^{186}$ so that employees of different employers are protected in working together for their "mutual aid." This policy has particular applicability in the minority worker context. Any successful effort to break down discrimination barriers in one company or industry is likely to have a beneficial impact in others. Thus, the NLRA protects minority workers from punitive action by their employer for their civil rights activities in combating job discrimination.

An interesting question is whether this policy should extend to protection of employees in their non-employment civil rights efforts. For instance, is a black worker who is fired because the employer disapproves of his outside activity with housing or school integration committees entitled to reinstatement? The worker could argue that there is a strong relationship between job discrimination and biased practices in other areas. As blacks achieve better educational and living conditions, their job opportunities will also increase. Thus, nonemployment civil rights activities of minority workers are substantially related to their "mutual aid and protection" as employees and ought to be protected by the Act.

Though the argument is an appealing one, it ought to be rejected. The prededents construing the scope of section 7 are clearly against it. All of the decisions in the area of protected employee activities have shown a considerable concern that the activity's objective be directly related to employment conditions. ${ }^{187}$ In its major

185. NLRB v. Peter Cailler Kohler Swiss Chocolates Co., 130 F.2d 503 (2d Cir. 1942); Fort Wayne Corrugated Paper Co. v. NLRB, 111 F.2d 869 (7th Cir. 1940); Cyril de Cordova \& Bros., 91 N.L.R.B. 1121 (1950).

186. National Labor Relations Act § 2(9), 29 U.S.C. § 152(9) (1964).

187. See American Art Clay Co. v. NLRB, 328 F.2d 88 (7th Cir. 1964); NLRB v. Dobbs Houses, lnc., 325 F.2d 531 (5th Cir. 1963); NLRB v. Phoenix Mutual Life ins. Co., 167 F.2d 983 (7th Cir. 1948); Plastelite Corp., 153 N.L.R.B. 180 (1965). 
pronouncement in this area, the Court also seemed to indicate that to be protected the activity concerned must grow out of a labor dispute ${ }^{188}$ - that is, "a controversy concerning, terms, tenure or conditions of employment." ${ }^{189}$ Most courts have held that employee strikers who seek to have supervisors reinstated are engaged in an area which is outside their immediate interest and within traditional managerial prerogatives. ${ }^{190}$ At least as strong a case can be made in that situation for the argument that the employee objective has an impact on employment conditions. Finally, decisions under section 7 have balanced employees' rights against policies favoring the employer's traditional freedom to operate his own business, ${ }^{191}$ and several cases have recognized the employer's power to make entirely arbitrary discharges. ${ }^{192}$ The danger of a holding that employers are prohibited by the NLRA from discharging employees for their involvement in general civil rights work is that it would open a Pandora's box. Logically extended, it would mean that employers would no longer be free to fire employees on the basis that they were involved in communist, fascist, socialist, Democratic, Republican or any other political or economic activities because all such groups intend ultimately to have an impact on working conditions in this country. Available evidence indicates that Congress never intended the Wagner Act to have such far-reaching impact in destroying the traditional employer prerogative to select his work forces. ${ }^{193}$

188. NLRB v. Washington Al. Co., 370 U.S. 9,15 (1962).

189. National Labor Relations Act § 2(9), 29 U.S.C. § 152(9) (1964).

190. See, e.g., American Art Clay Co. v. NLRB, 328 F.2d 88 (7th Cir. 1964); Dobbs Houses, Inc. v. NLRB, 325 F.2d 531 (5th Cir, 1963); Cleaver-Brooks Mfg. Corp. v. NLRB, 264 F.2d 637 (7th Cir.), cert. denied, 361 U.S. 817 (1959). The Board protects employee protests over the removal of a supervisor when the "identity and capability of the supervisor involved has a direct impact on the employees' own job interests and on their performance of the work they are hired to do." Dobbs Houses, Inc., 135 N.L.R.B. 885, 888 (1962) vacated, 325 F.2d 531 (5th Cir. 1963). See also Getman, The Protection of Economic Pressure by Section 7 of the National Labor Relations Act, 115 U. PA. L. Rev. $1195,1211-18$ (1967).

191. See, e.g., NLRB v. Union Steelworkers, 357 U.S. 357 (1958); NLRB v. Babcock \& Wilcox Co., 351 U.S. 105 (1956); NLRB v. Mackay Radio \& Telegraph Co., 304 U.S. 333 (1938); Elk Lumber Co., 91 N.L.R.B. 333 (1950).

192. Hagopian \& Sons, Inc. v. NLRB, 395 F.2d 947, 950-51 (6th Cir. 1968); NLRB v. United Parcel Service, Inc., 317 F.2d 912, 914 (1st Cir. 1963); NLRB v. McGahey, 233 F.2d 406, 413 (5th Cir. 1956).

193. Senator Walsh made the following statement in seeking passage of the Wagner Act: Mr. President, there are some fundamental rights an employer has, just as there are rights an employee has. No one can compel an employer to keep his factory open. No one can compel an employer to pay any particular wage. No one can compel an employer to hire others in addition to those he sees fit to hire. . . .

So in dealing with this bill we have to recognize those fundamental things, and we 
2. Concerted Employee Activities in Unionized Situation. When employees engage in an independent protest in a unionized plant without union authorization, special problems arise regarding whether the conduct should be protected. After a collective bargaining representative is selected, the assumption of the NLRA is that there is an adequate vehicle through which most employee protests can be channeled. Moreover, independent employee efforts cause some concern that the union's status as exclusive bargaining representative will be undermined. ${ }^{194}$ Most of the cases in this area have arisen in wildcat strike situations. The courts have generally held such strikes are unprotected, ${ }^{195}$ while the Board has protected the strikers when it has found an identity between their objectives and those of the union. ${ }^{195}$

In Tanner Motor Livery Ltd. ${ }^{197}$ two white drivers, active in civil rights work, were found to have been discharged for picketing in protest against their company's failure to hire a black driver. The Board held that such conduct was protected, citing New Negro Alliance v. Sanitary Grocery Co., ${ }^{198}$ and ordered that the employees be reinstated. On appeal, the Ninth Circuit remanded the case to the Board for consideration of the question of whether these employees were required to file their protests through their union. ${ }^{199}$ The court put the question as follows: "to what extent does Section 9(a) [making the union the exclusive bargaining representative] limit or remove the protection afforded by Section 7?"'200 On remand, the Board applied its general approach to independent employee action in unionized plants. ${ }^{201}$ It stated that the conduct should be protected because it

have not gone into that domain. All we do is to remove the barriers tbat have kept employees away from their employer, which have prevented collective bargaining, which have resulted in strikes without any attempt to negotiate. All we have done is to promote the orderly processes of collective bargaining. 79 CONG. REC. 7673 (1935).

In NLRB v. Jones \& Laughlin Steel Corp., 301 U.S. I (1936), the Court said that "[t]he Act does not interfere with the normal right of the employer to select its employees or to discharge them." Id. at 45. See also NLRB v. Superior Co., 199 F.2d 38, 42 (6th Cir. 1952).

194. See Getman, supra note I90, at 1197.

195. NLRB v. Shop Rite Foods, Inc., 430 F.2d 786 (5th Cir. 1970); Plasti-Line, Inc. v. NLRB, 278 F.2d 482 (6th Cir. 1960); NLRB v. Draper Corp., 145 F.2d 199 (4th Cir. 1944). Contra NLRB v. R.C. Can Co., 328 F.2d 974 (5th Cir. 1964).

196. Sunbeam Lighting Co., 136 N.L.R.B. 1248 (1962), enforcement denied, 318 F.2d 661 (7th Cir. 1963). See generally Gould, The Status of Unauthorized and "Wildcat" Strikes Under the National Labor Relations Act, 52 CORNELL L.Q. 672 (I967).

197. 148 N.L.R.B. 1402 (1964).

198. 303 U.S. 552 (1938).

199. 349 F.2d I (9th Cir. 1965).

200. Id. at 3 .

201. 166 N.L.R.B. 551 (1967). 
assumed that the union was acting lawfully and therefore shared the objeetive of the employees to eliminate racial discrimination in the company. Thus, whether the employees filed a grievance with the union was irrelevant because under the Board's view, even independent employee action is protected when it is consistent with general union goals. On a second appeal, the Ninth Circuit rejected the Board's theory, ${ }^{202}$ interpreting a long series of judicial opinions ${ }^{203}$ to mean that independent employee action requires specific union authorization in order to be protected. The case was remanded to determine whether the employer had an obligation to inform the employees of the requirement that they file their grievances with the union before dismissing them. ${ }^{204}$

Commentators have questioned the Board's assumption that independent employee actions do not undermine the exelusive power of the union simply because there is an identity of union-employee objectives. ${ }^{205}$ It is contended, for example, that a disruption in the union's time plan for a strike caused by a wildcat walkout in support of the union's economic objectives may destroy the union's entire strike strategy ${ }^{206}$ In line with this criticism, the majority of courts appear to be rejecting the Board's theory. Nevertheless, whatever the relative merits of the Board and court positions in a wildcat strike context, both were incorrect in Tanner Livery in assuming that these policies should be applied absolutely to minority worker protests. The assumptions behind the creation of rules for wildcat strikes simply do not apply in the equal employment opportunity area. Given the vast evidence which documents discrimination by union insiders against minority group members, ${ }^{207}$ it cannot be assumed that the union is an adequate forum for the expression and fulfillment of minority interests. To the extent that discrimination against minorities exists in a company, the union as co-negotiator and administrator of the collective bargaining agreement may be as responsible as the company for it and equally interested in its

202. NLRB v. Tanner Motor Livery Ltd., 419 F.2d 216 (9th Cir. 1969).

203. See note 195 supra.

204. A lengthy discussion of the Tanner Livery case is contained in Gould, Black Power in the Unions: The Impact Upon Collective Bargaining Relationships, 79 YALE L.J. 46, 5772 (1969).

205. Gould, supra note 196, at 685-88. See also Getman, supra note 190, at 1246-47.

206. Gould, supra note 196 , at 687.

207. See Hill, The Racial Practices of Organized Labor: The Comtemporary Record, in The Negro and the american Labor Market 286-358 (1968). See generally F. Marshall. \& V. Briggs, The Negro and Apprenticeship (1967); R. Marshall, The Negro and Organized Labor (1965). 
continuance. When minorities are working to eliminate discrimination which exists in a plant, they cannot be considered to be undermining the union's role for they are doing precisely what the union ought to be doing for them in fulfillment of its duty of fair representation. The likelihood that unions are violating their duty of fair representation-either actively or passively-in cases of independent minority protest, is very great. The facts in Tanner Livery indicate a possibility that the union was, in fact, violating its duty in that case. ${ }^{208}$ The Board and courts, both of which ignored this issue in Tanner Livery, should be keenly concerned about this possibility in every such case they consider.

In a Tanner Livery situation, the Board should not apply its normal wildcat striker rules and protect the activity only when the union and protestors have common objectives. A situation in which the union was supporting existing discrimination and opposing the goals of the minority workers would be the very strongest possible case for protection of the independent minority efforts. Moreover, the courts should not require in all such cases that grievances be filed with the union, for this implies that the minority workers have an obligation to delay their efforts until the union takes action. An unsympathetic union could kill the protest by long delay or lackadaisical pursuit of the employees' interest. Instead, the Board should first attempt to determine whether discriminatory practices do, in fact, exist. If they do, the minority protest should be protected unless there is evidence that the union is engaged in its own vigorous program to remove the discrimination. When the union is actively opposing the discrimination through a plan of its own, the minority protest should not be allowed because it might, then, undermine the union's strategy. In the absence of such a program, the ultimate Board decision might properly include not only an order protecting

208. In Tanner Livery, the union first refused to process the grievances of a driver who was discharged for his civil rights efforts and then later joined the company in deciding that he was not entitled to reinstatement. The evidence indicated that the union sympathized with the employer's position. Gould, supra note 204, at 57, 60. In Emporium and Western Addition Community Org., 192 N.L.R.B. No. 14, 77 L.R.R.M. 1669 (197I), the Board refused to protect picketing by a group of blacks which was designed to climinate employer racial discrimination. The Board's result was based on the view that the employees should have worked through the union which was already protesting the discrimination on its own, though apparently in a very slow and deliberate manner. The majority opinion is very brief, essentially an adoption of the trial examiner's views. However, an argument can be made that the 3-2 decision marks an even stronger Board posture against independent minority protests than Tanner Livery, for the Board might have protected this picketing, like the picketing in Tanner, on the basis that the employees and the union were united in their "objectives" and disagreed only about "means." 
the minority protest but also a finding that the union was committing an unfair labor practice by failing to represent the minority workers adequately. In such a case, appropriate remedial orders could be issued against the union as well as against the employer.

Employer Discrimination in the Absence of Concerted Protest-Packinghouse Workers. In United Packinghouse, Food \& Allied Workers v. NLRB ${ }^{209}$ there was evidence that a cotton processor employer was engaged in extensive racial discrimination against black and Latin American workers. The Board held that his refusal to bargain with the union regarding the elimination of these conditions violated 8(a)(5). ${ }^{210}$ On appeal, the union argued that the discriminatory practices violated section $8(a)(1)$ and (3). Somewhat surprisingly, the District of Columbia Circuit Court agreed with the union's 8(a)(1) theory. The court argued that a pattern of invidious discrimination sets up a clash of interests between minorities and other workers, reducing their ability to work together and produces in its victims an apathy which inhibits them from asserting their section 7 rights. The court believed "that the confluence of these two factors sufficiently deterred the exercise of Section 7 rights as to violate Section 8(a)(1)."211 The case was remanded to the Board to determine whether an invidious pattern of employer discrimination existed.

As previously indicated, ${ }^{212}$ the Packinghouse view could have considerable impact in removing limitations on the Board's role in equal employment cases. Under its theory, the NLRA could also have enhanced remedial power. It could go beyond the protection of concerted protests to orders requiring the removal of all elements of employment discrimination in a company on the basis that such discrimination stifles section 7 rights. Moreover, it could handle complaints of employment discrimination even absent concerted protest since the mere existence of discriminatory conditions would be a violation of the Act. Although the Packinghouse opinion speaks only of situations in which a pattern of discrimination exists in a company, the doctrine might be extended in the future to individual acts of discrimination, because such acts also create a cleavage between minority employees and others and contribute to minority apathy.

209. 416 F.2d 1126 (D.C. Cir.), cert. denied, 396 U.S. 903 (1969).

210. 169 N.L.R.B. 290 (1968).

211. 416 F.2d at 1135.

212. See notes 5-15 supra and accompanying text. 
The most significant aspect of the Packinghouse opinion is its concern for the protection of the potential conditions for concerted activities. Unlike the Tanner Livery, ${ }^{213}$ Mason \& Hanger-Silas Mason Co. ${ }^{214}$ and Building Service Employees ${ }^{215}$ cases, the court in Packinghouse was not concerned with situations in which minority employees were actually protesting, striking or picketing to improve their position. In fact, Packinghouse seems primarily directed toward cases where such protest activities are not occurring because minority employees have been too intimidated to assert themselves.

It is difficult to find precedent supporting the view that the Board should protect employees' potential psychological attitudes toward concerted activities. The Packinghouse opinion does not cite relevant case authority, but rather relies, primarily, upon the analyses of several sociologists concerning the impact of discrimination on employee attitudes. ${ }^{216}$ Although there have been situations in which the Board has been concerned with the psychological effect of employer action on employee attitudes, most such cases have occurred in a unionization context where the employer made threats or took punitive action against workers in an effort to discourage them from supporting union activity. ${ }^{217}$ These situations are clearly distinguishable from Packinghouse. First, they deal directly with the employees' rights to unionize-a more central and primary concern of the Act than the right to engage in concerted activity in general. ${ }^{218}$ Secondly, they concern situations where collective activity is already occurring.

Unlike the union discrimination situation, the NLRA has no special concern with independent employer discrimination against minorities. Therefore, the sole basis for the Board's involvement in Packinghouse is the Act's policy favoring protection of concerted activities in general. This means that if the court's position is sound,

213. 148 N.L.R.B. 1402 (1964).

214. 179 N.L.R.B. No. 71,72 L.R.R.M. 1372 (1969).

215. 188 N.L.R.B. No. 141 , 76 L.R.R.M. 1467 (1971).

216. 416 F.2d at 1136-38. The court cited K. Clark, Dark Ghetto (1965); G. Myrdal, An American Dilemima $391-92$ (1944); and H. Witmer \& R. Kotinsky, Personality in the MAKING ch. Vl (1952).

217. See, e.g., Textile Workers v. Darlington Mfg. Co., 380 U.S. 263 (1965) (partial shutdown as threat against union activity); NLRB v. Exchange Parts Co., 375 U.S. 405 (1964) (promise of benefits before union election construed as threat that benefits would dry up if union was elected); NLRB v. Erie Resistor Corp., 373 U.S. 221 (1963) (adverse psychological impact on union activity as result of super-seniority offer to strike replacements); NLRB v. Golub Corp., 388 F.2d 921 (2d Cir. 1967) (threats against unionization).

218. See National Labor Relations Act \& 1, 29 U.S.C. § 151 (1964). 
it would be necessary to extend it beyond minority problems. Thus, any employer who arbitrarily classifies his employees and establishes harsh and unfair working conditions for certain groups would also be violating 8(a)(1). For instance, if he paid one group of his maintenance workers at extremely low, unfair rates and subjected them to excessively harsh working conditions, he would be interfering with their section 7 rights. These workers are also capable of becoming apathetic and docile under the employer's tyranny. A cleavage would also be created between their interests and those of the other employees, reducing the likelihood of their working in concert. The Packinghouse court seems to be arguing that blacks and other minorities are more likely to develop apathetic attitudes as the result of discrimination than are other workers. ${ }^{219}$ The sociologists the court relied upon in reaching this judgment, however, were writing about minority attitudes in periods earlier than the 1970's. 220 The emergence of the black power movement, the new sense of "La Raza" and "La Causa" in the Mexican-American community and women's liberation makes one suspect that a psychological reaction of indignation and minority pride may be just as likely as a reaction of docility today. ${ }^{221}$ These reactions may spur concerted protests rather than prevent them. Even if general sociological conditions indicate that job discrimination more deeply disturbs minority workers psychologically, they may also indicate that there is more hikelihood of community action by such workers. Groups of minority employees have a natural cohesion and common bond that other workers lack. It is therefore impossible to say that employer discrimination has a more chilling impact on minority concerned action than on non-minority group efforts. If the former are covered by the Packinghouse doctrine, the latter should also be covered. The union duty of fair representation theory necessarily extends beyond minority employees to arbitrary union action toward any workers. The Packinghouse theory would have to be similarly extended. Therefore, it would take the Board into a new area of responsibilitythe general surveillance of working conditions to ensure that proper circumstances for the realization of concerted protests exist.

219. See 416 F.2d at 1135 n. 15 .

220. See note 207 supra. Kenneth Clark was concerned with the early 1960's, Witmer \& Kotinsky with the early 1950's, and Gunnar Mysdal wrote about black attitudes in the 1940's.

221. See generally J. BuRma, Mexican-Anericans in the United States 279-324 (1970); R. Endo, W. Strawbridge, Perspectives on Blacx America 182-203 (1970); R. Young, Roots of Rebellion-The Evolution of Black Politics and Protest Since World War II (1970); Komisar, The New Feninism, SATURday Review, Feb. 2I, 1970. 
This would be an undesirable extension of the Board's authority. Congress clearly never intended it to have the power to review the reasonableness of working conditions established by an employer. ${ }^{222}$ Decisions under the Act have traditionally recognized the employer's freedom to act arbitrarily, absent a compelling statutory policy to the contrary. ${ }^{223}$ By addressing employer as well as union discrimination, the statute would also serve another purpose Congress did not intend it to perform-the general remedying of all equal employment violations. ${ }^{224}$

In the absence of alternative civil rights remedies, there might be more reason for the Board to play a major role in employer discrimination. Given the existence of Title VII, however, the problem is one of striking a proper balance between the legitimate, independent interests of the NLRA and the carefully designed procedures Congress has provided for minority discrimination cases. Despite the resultant overlap, the policies and interests of the NLRA justify a major Board role in union discrimination and in cases where the employer is interfering with actual minority concerted protests. There are, on the other hand, no similar policies supporting an extension of Board authority to cases of independent employer discrimination. A proper analysis of the Act's policies indicates that the only appropriate role for the Board in Packinghouse-type cases is to direct complainants to other equal employment agencies which are specifically designed to handle them. ${ }^{225}$

\section{See note 193 supra.}

223. Textile Workers v. Darlington Mrg. Co., 380 U.S. 263 (1965). See cases cited in note 184 supra regarding the employer's right to make entirely arbitrary discharges. The following cases also speak about traditional employer freedoms in the operation of his business with which the Act could not interfere absent a compelling need. United States v. United Steelworkers, 357 U.S. 357 (1958); NLRB v. Babcock \& Wilcox Co., 35 I U.S. 105 (1956); Peyton Packing Co., 49 N.L.R.B. 828 (1943), enforced 142 F.2d 1009 (5th Cir.), cert. denied, 323 U.S. 730 (1944).

224. See note 11 supra and accompanying text.

225. The General Counsel's suggested variation of the Packinghouse theory is even less persuasive than the D.C. Circuit Court of Appeals' argument. See note 5 supra. In his Quarterly Report, the General Counsel indicated that he intended to prosecute a case where the employer refused to bargain with the union about the elimination of discriminatory working conditions. The General Counsel stated that the employer violated $8(a)(1)$ by demonstrating the union's ineffectiveness to the employees, undermining their faith in working through the union. However, this employee reaction is likely to occur whenever the employer rejects a union demand. To say that the employer's causing such a reaction is an unfair labor practice would be to require bim to yield on all important union demands-a result that the Act clearly does not contemplate. 


\section{CONCLUSION}

The NLRB has a significant equal employment potential. Interpretation of the NLRA indicates that the Board has authority to utilize its unfair labor practice procedures to combat union discrimination. The constitutional and historical statutory interests of the Act in this area justify a Board role in spite of the existence of more explicit civil rights provisions. Six years of experience with Title VII's weaknesses confirms this conclusion. Any dangers of overlapping authority and duplicative efforts by the Board and other agencies can clearly be avoided by the development of appropriate liaison and rules of accommodation at the administrative level. ${ }^{226}$

The Board also has an important function in two types of employer discrimination cases. The first occurs when the employer supports and contributes to union discrimination. The second category concerns situations where the employer takes punitive action against minority employees because of their involvement in concerted protests. In these areas, the NLRB offers the advantage of public enforcement over other equal employment agencies. However, it also has special limitations which do not exist in express civil rights statutes. Thus, the Board does not have broad remedial power to eliminate discriminatory conditions when an employer interferes with a concerted minority protest-its authority is limited to an order requiring a return to the status quo. Moreover, Packinghouse notwithstanding, the Act does not support the conclusion that independent discriminatory acts by employers or the general existence of discriminatory working conditions in a company are unfair labor practices.

To the extent that the Board does have a function in this area, it is clear that its current potential is not being realized. A number of reported minority discrimination cases closely followed the Miranda decision ${ }^{23}$ but there have been relatively few such cases in recent years. Evidently, the passage of Title VII and the emergence of section $198 \mathrm{I}$ cases have turned the attention of discrimination victims away from the NLRA. The flood of cases, predicted and feared by the critics of Miranda ${ }^{228}$ on the basis that it would

226. See notes 92-102 supra and accompanying text.

227. See cases cited in note 3 supra.

228. See NLRB v. Miranda Fuel Co., 326 F.2d 172, 176 (2d Cir. 1963). In rejecting the Board's Miranda theory, the court said:

We pause to observe that against the background of the present nationwide interest in discrimination for reasons of race, nationality, color or religion, and the natural 
overwhelm the Board's capacities, has never developed. The number of cases has been too small to cause concern about the Board's ability to handle them. Even the commentators appear to have lost some of their early interest in the Board's potential. A raft of articles appeared in the early and mid-1960's regarding the NLRB and racial discrimination ${ }^{229}$ but there has been relatively little written in this area in recent years. ${ }^{230}$

The reason for the shortage of cases may lie in the law's uncertainty. The Board itself split in Miranda, ${ }^{231}$ and its division has continued in subsequent cases. ${ }^{232}$ Only three circuits have resolved the Miranda question, ${ }^{233}$ and one has decided against the Board's theory. ${ }^{234}$ The Supreme Court has been reluctant to take a stand on the issue. 235 Thus, the victim of discrimination who opts for NLRB procedures is a pioneer in the majority of circuits, traveling on an uncertain path without even knowing whether he has a legal right under the Act until a circuit court of appeals reviews his case at the end of his exploration. Despite uncertainties regarding its role, the Board would appear to offer an attractive option to the victim of discrimination who cannot or does not wish to bring a private action. For such a person the Board's procedures should be a far more desirable alternative than total abandonment of his claim.

It is interesting that the uncertainty has lasted so long. Miranda

tendency of human beings to attribute their lack of success to discrimination of one kind or another against them, it seems inevitable that the Board would be inundated with charges of this character, were we to sustain the ruling of the Board in this case.

229. Carter, The National Labor Relations Board and Racial Discrimination, 2 LAW IN TRANSITION Q. 87 (1965); Herring, The Fair Representation Doctrine: An Effective Weapon Against Union Racial Discrimination?, 24 MD. L. REv. 113 (1964); Molinar, The National Labor Relations Act and Racial Discrimination, 7 B.C. IND. \& CoMm. L. Rev. 601 (1966); Sherman, Union's Duty of Fair Representation and the Civil Rights Act of 1964, 49 MinN. L. REv. 771 (1965); Sovern, The National Labor Relations Act and Racial Discrimination, 62 COLUM. L. REV. 563 (1962).

230. There has been only one comprehensive law review lead article devoted to this topic in recent years-Boyce, Racial Discrimination and the National Labor Relations Act: A Survey, 65 Nw. U.L. REv. 232 (1970). It is written by a Regional Attorney for the National Labor Relations Board, and primarily surveys many of the cases in the area, suggesting a shift in the burden of proof in race discrimination cases. (1962).

231. Only three of five Board members voted for the Miranda result. 140 N.L.R.B. 181

232. A brief analysis of recent voting patterns by Board members on this issue is contained in Boyce, supra notc 230 , at 257 n.84.

233. Truck Drivers Local 586 v. NLRB, 379 F.2d 137 (D.C. Cir. 1967); URW Local 568 v. NLRB, 368 F.2d 12 (5th Cir. 1966); NLRB v. Miranda Fuel Co., 326 F.2d 172 (2d Cir. 1963).

234. NLRB v. Miranda Fuel Co., 326 F.2d 172 (2d Cir. 1963).

235. See cases cited in note 30 supra. 
is now almost ten years old and the discussion of a possible role for the Board in minority discrimination cases began long before Miranda was decided. ${ }^{236}$ The issue appears to be more than ripe for resolution by the Supreme Court. The question is one of considerable significance and the circuit courts of appeal are in conflict. The Supreme Court may have felt safe in avoiding the issue thus far because of the small number of cases in the area. If disillusion with Title VII continues, however, it is highly possible that more unfair labor practice complaints by discrimination victims will be filed under the NLRA. If that happens, the Court may find it necessary to clarify the Board's equal employment role within the next few years. That decision should finally determine the full ramifications of the Steele case. After almost thirty years of uncertainty and controversy, it is awaited with great interest.

236. For early discussions regarding the Board's potential in duty of fair representation cases, see Cox, The Duty of Fair Representation, 2 Vill. L. Rev. 151, 172-75 (1957); Wellington, Union Democracy and Fair Representation: Federal Responibility in a Federal System, 67 YALE L.J. 1327, 1357-61 (1958). 